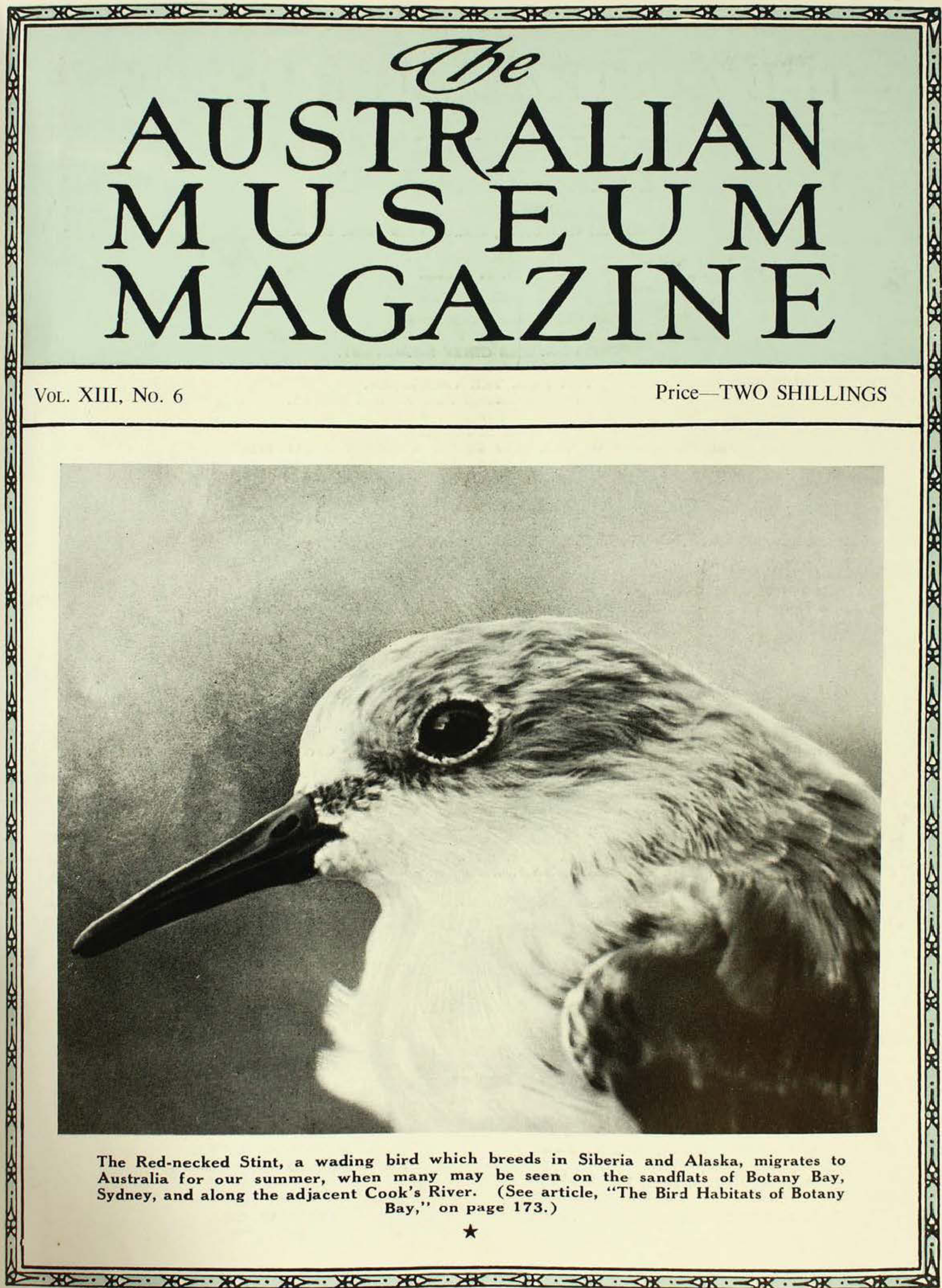

Registered at the General Post Office, Sydney, for transmission as a periodical. 


\title{
THE AUSTRALIAN MUSEUM
} HYDE PARK, SYDNEY

\section{B OARD OF TRUSTEES}

\author{
PRESIDENT: \\ WALLACE C. WURTH, C.M.G., LL.B., Hon. LL.D. \\ CROWN TRUSTEE: \\ F. B. SPENCER. \\ OFFICIAL TRUSTEES:
}

THE HON. THE CHIEF JUSTICE.

THE HON. THE PRESIDENT OF THE LEGISLATIVE COUNCIL.

THE HON. THE CHIEF SECRETARY.

THE HON. THE ATTORNEY GENERAL.

THE HON. THE TREASURER.

THE HON. THE MINISTER FOR PUBLIC WORKS.

THE HON. THE MINISTER FOR EDUCATION.

THE AUDITOR-GENERAL.

THE PRESIDENT OF THE NEW SOUTH WALES MEDICAL BOARD.

THE SURVEYOR-GENERAL AND CHIEF SURVEYOR.

THE CROWN SOLICITOR.

O. G. VICKERY, B.E., M.I.E. (Aust.). WALLACE C. WURTH, C.M.G., LL.B. PKUF. A. P. ELKIN, M.A., Ph.D. F. MCDOWELL.

R. J. NOBLE, C.B.E., M.Sc., Ph.D.

E. J. KENNY, M.Aust. I.M.M.

\section{ELECTIVE TRUSTEES :}

F. L. S. BELL, M.A., F.R.A.I.

FRANK W. HILL.

G. A. JOHNSON.

PROF. R. L. CROCKER, D.Sc

PROF. J. R. A. McMillaN, M.S., D.Sc.Agr.

E. A. J. HYDE.

\section{DIRECTOR : \\ J. W. EVANS, Sc.D. \\ DEPUTY DIRECTOR : \\ H. O. FLETCHER, M.Sc.}

SCIENTIFIC STAFF :

Birds, Reptiles and Amphibians: J. A. KEAST, M.A., M.Sc., Ph.D., Curator; H. G. COGGER, B.Sc. (Gen. Sc.), Assistant Curator.

Mammals: B. J. MARLOW, B.Sc., F.Z.S., Curator.

Fishes: G. P. WHITLEY, F.R.Z.S., Curator.

Insects and Arachnids: C. N. SMITHERS, M.Sc., Curator; D. K. McALPINE, M.Sc., Assistant Curator. Molluses: D. F. McMICHAEL, M.A., Ph.D., Curator.

Crustacea and Coelenterates: F. A. McNEILL, Curator.

Worms and Echinoderms: ELIZABETH C. POPE, M.Sc., Curator.

Minerals and Rocks: R. O. CHALMERS, A.S.T.C., Curator.

Fossils: H. O. FLETCHER, M.Sc., Curator.

Anthropology: F. D. McCARTHY, Dip.Anthrop., Curator.

\section{EDITORIAL ASSISTANT AND PUBLIC RELATIONS OFFICER: PETER COLLIS.}

\section{EXHIBITION DEPARTMENT, ART AND DESIGN SECTION: \\ F. J. BEEMAN.}

LIBRARIAN:

MARY DAVIES, B.Sc., L.A.A.
PREPARATION SECTION:

R. D. MACKAY
EDUCATION OFFICER :

PATRICIA M. MeDONALD, B.Sc., Dip.Ed.
PHOTOGRAPHER AND VISUAL AIDS OFFICER: H. HUGHES.

HONORARY SCIENTIFIC STAFF : Zoologists.

E. A. BRIGGS, D.Sc.

H. LEIGHTON KESTEVEN, D.Sc., M.D. MELBOURNE WARD, F.R.Z.S., F.Z.S. TOM IREDALE.

A. J. MARShall, D.Sc., D.Phil. Ornithologist.

K. A. HINDWOOD, C.F.A.O.U., F.R.Z.S,
JOYCE ALLAN, F.R.Z.S.

S. J. COPLAND, M.Sc.

ELLIS TROUGHTON, F.R.Z.S.

A. A. RACEK, Dr, rer, nat. (Brno).

Philatelist.

FRANK W. HILL 


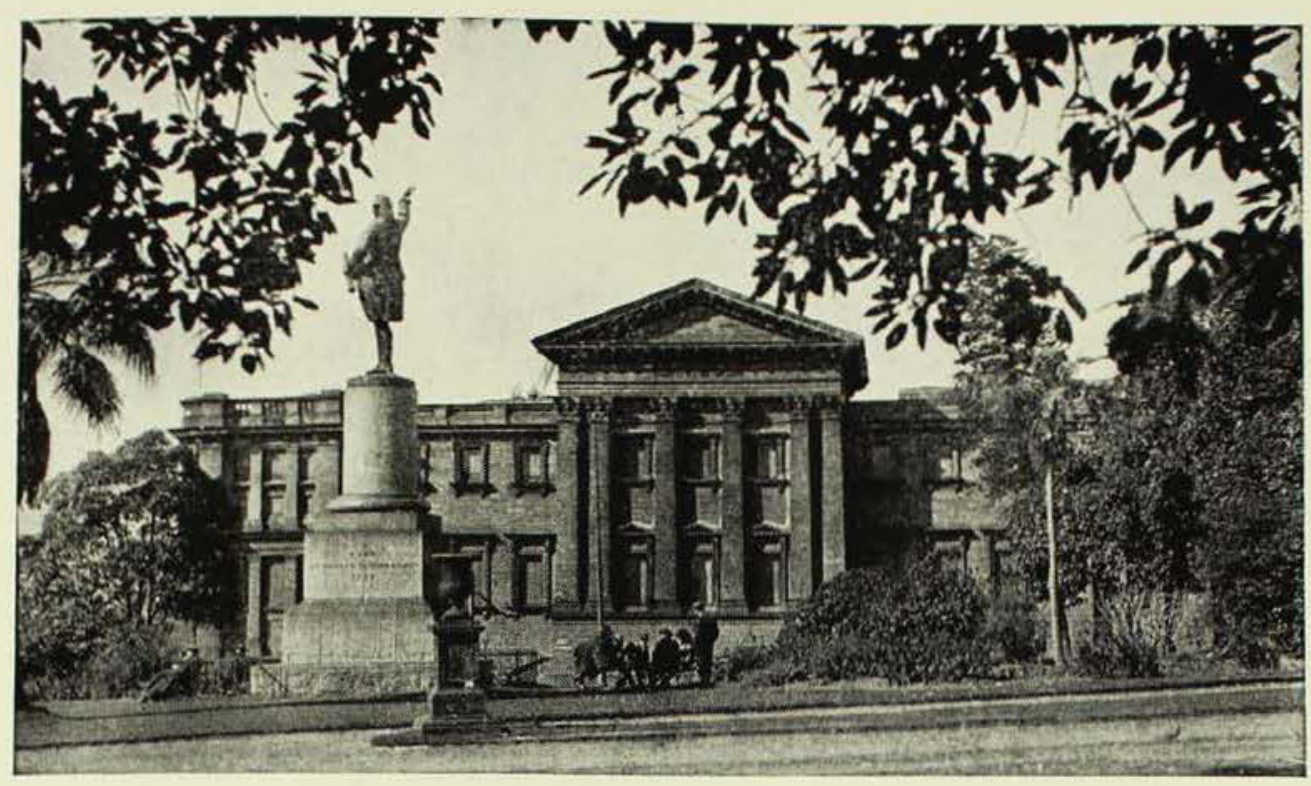

\section{CONTENTS}

Page

The Bird Habitats of Botany Bay-Arnold R. McGill $\quad \ldots \quad \ldots \quad \ldots \quad 173$

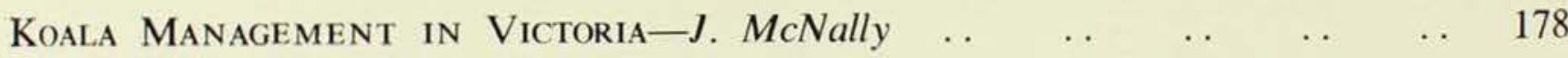

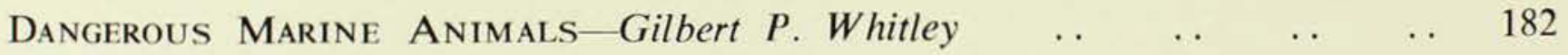

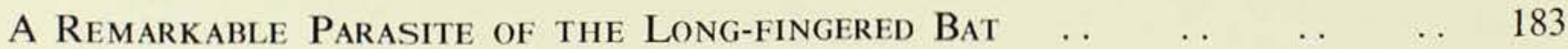

The Evolution and Radiation of Mammals-B. J. Marlow $\quad \ldots \quad \ldots \quad \ldots \quad \ldots \quad 184$

$\begin{array}{llllllllllll}\text { The Corroboree Frog } & \ldots & \ldots & \ldots & \ldots & \ldots & \ldots & \ldots & \ldots & \ldots & 190\end{array}$

Turtles of the PASt-H. O. Fletcher $\quad \ldots$.

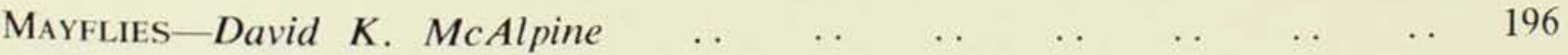

“The Vertebrate Tree"

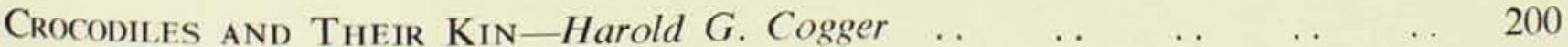

The fine study of a Red-necked Stint on our front cover was taken by Arnold R. McGill, secretary of the New South Wales branch of the Royal Australasian Ornithologists' Union, author of the article, "The Bird Habitats of Botany Bay." The Red-necked Stint is one of 25 species of waders breeding in eastern Asia which have been recorded from Botany Bay.

VOLUME XIII, NUMBER 6.

JUNE 15,1960 


\section{NEW BOOKS \\ CONSPIRACY OF SILENCE \\ by Peter Eton and James Leasor}

In 1941 four German soldiers in Yugoslavia captured a truckload of gold bullion. Two years later the great loot of Rommel's Afrika Korps was dumped overboard from the special ship taking it to Germany. But when the authors tried to trace these treasures they came up against a vicious, sinister conspiracy of silence. Illustrated.

\section{THE LOTUS AND THE DYNAMO by C. D. Rowley}

A tale of travel in strange lands, and a thoughtful study of an important part of the world-Laos, Cambodia, Thailand, Vietnam, Indonesia and the Philippines. The author is a sympathetic and alert observer. Illustrated. . . 30/- (post 1/3)

\section{A DESCANT FOR GOSSIPS \\ by Thea Astley}

"Tells with satirical but serious perception the story of two middle-aged schoolteachers who are driven by sympathy and loneliness-his wife is an incurable invalid-into each other's arms . . . caustic and convincing in satire." (Times Literary Supplement)

\section{GAMBOLS IN GASTRONOMY}

by William Wallace Irwin

Delectable recipes by the Garrulous Gourmet-to be used (and enjoyed) both by girls who have a man to feed and by men who like browsing through cook books. $25 /-($ post $1 / 3$ )

\section{NO BOUNDARY FENCE \\ by Frank O'Grady}

This novel brings to life Hamilton Hume, both as a brave, capable, fiery-tempered man, and as a famous explorer who made his first important trip at seventeen. It tells of his love for Elizabeth Dight, and how in his later life he dealt with bushrangers and avenged the tragic death of his brother. ... 20/- (post 1/3)

\section{MEETING SOVIET MAN by Manning Clark}

An attempt to discover the real feelings, hopes and fears of Russian men and women today. The author makes many illuminating comments on Russians' outlook and manners, and on East-West relationships today. . . 15/- (post 10d.)

\section{At all booksellers}

\section{ANGUS \& ROBERTSON (PUBLISHERS) PTY LTD}




\section{TH E A U S T R A L I A N MUSEUM MAGAZINE}

Published Quarterly by the Australian Museum

Editor: J. W. Evans, Sc.D.

College Street, Sydney

Annual Subscription, Posted, 10/-

VoL. XIII, No. 6

JUNE 15,1960

\section{THE BIRD HABITATS OF BOTANY BAY}

By ARNOLD R. McGILL

Secretary of the New South Wales branch of the Royal Australasian Ornithologists' Union

W HEN Captain James Cook first set foot on Australian soil nearly 200 years ago he justifiably named his landing place Botany Bay. The ornithological history of the area also began in 1770 , for in his M.S. Journal, now in the Mitchell Library, [Sir] Joseph Banks states:-

May 1. "... The tree over our heads abounded very much with Loryquets and cocatoos of which we shot several, both these sorts flew in flocks of several score together ...."

May 2. "Tupia, a native of the Hawaiian Islands who strayed from us in pursuit of Parrots of which he shot several ..."

May 3. ". . . I made a small excursion in order to shoot any thing I could meet with \& found a large quantity of Quails much resembling our English ones [Stubble Quail] of which I might have killed as many almost as I pleased had I given time up to it but my business was to kill variety and not too many individuals of any one species."
During the early days of settlement the "Botany Swamps" became a favourite rendezvous for the "sporting" fraternity. No doubt collectors patronized the locality as well, and the many references given in the writings of A. J. North bear testimony to its popularity. Species that reached the Museum from there, or are mentioned in literature, include the Avocet, Banded Stilt and Freckled Duck, which have not been subsequently observed in the Botany swampland, and the Corncake, which has only been obtained once since in Australia.

\section{Variety Of Habitats}

I have long taken a particular interest in the birds of Botany Bay, but feel that the bay's real appeal lies in the variety of habitats suitable for bird life to be found there. Because of the nature of the soil, rain forest has probably never existed close to the shores of Botany Bay, but most other types of avian habitat - open forest, heathland, mangroves, cultivation, grassland, swamps, estuaries, tidal-flats and oceanstill persist to varying extents.

A 10 mile square, as shown in the accompanying map, readily forms a boundary to the whole area, which extends 


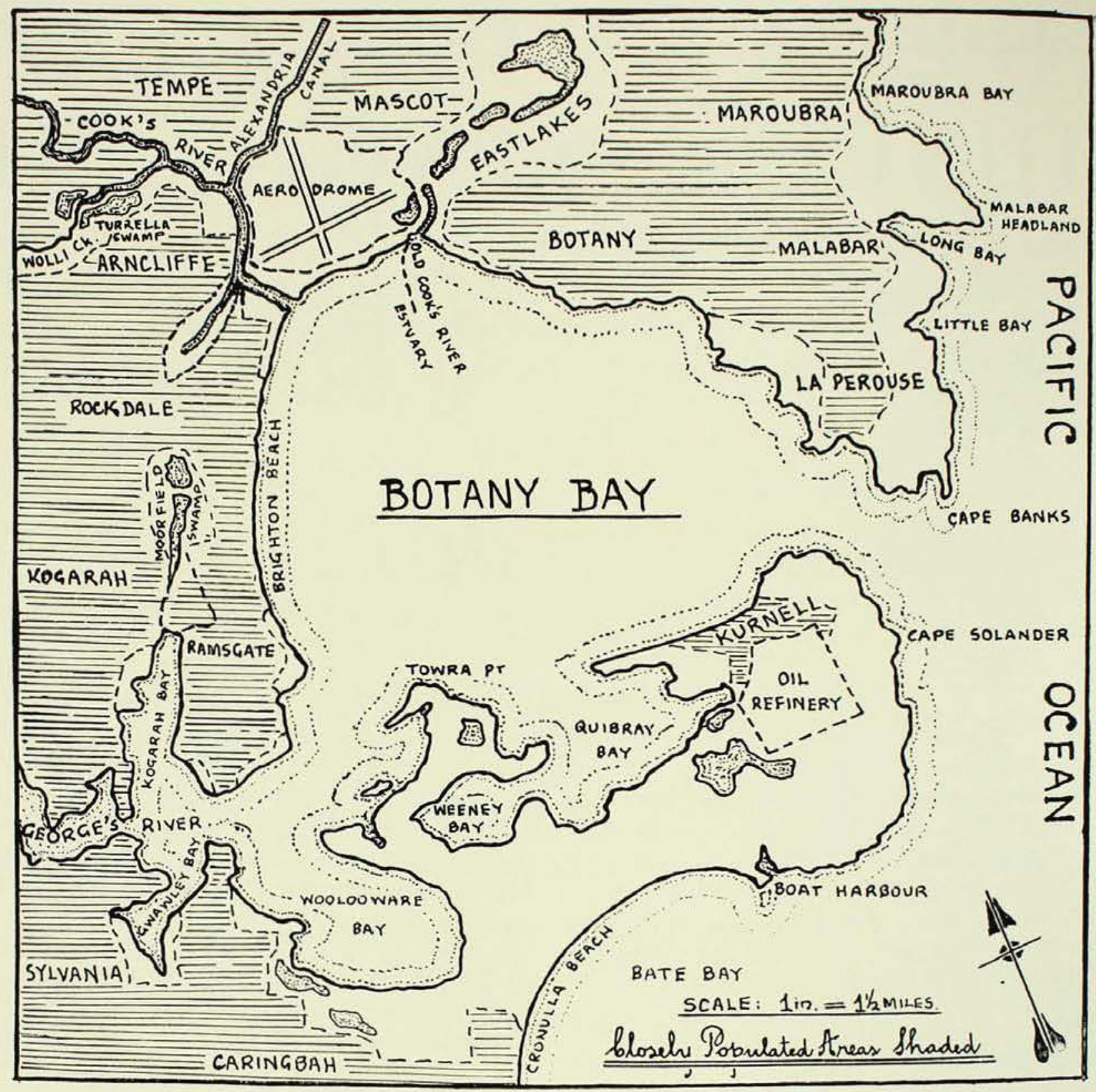

The Botany Bay area.

Drawn by the Author.

north to Alexandria Canal and Eastlakes Water Reserve, south to the limits of Woolooware Bay, west to the George's River estuary and east to the Pacific Ocean. Some parts are still sparsely inhabited, especially on the south side, and have probably changed little by the impact of settlement. Mangrove swamps, samphire flats and sandy heathland have not in the past proved inviting places for close habitation, but modern methods in draining and filling-in such localities have changed that view and the ornithological future of Botany Bay must cause concern. What birds will be recorded there in years to come, unless much of this original habitat be preserved as close fauna and flora reserves, will depend on each species' ability to adapt itself to artificial parks and lakes. which, fortunately, appear to be requirements of modern subdivision planning.

Nearly 300 species of birds have been recorded within the geographical confines of Botany Bay, even though the whole area is within the Metropolitan boundary of the City of Sydney. To enumerate, and deliberate on, all these species would require a comprehensive account, so only some that are noteworthy or prominent will be mentioned when discussing the various habitats. 
Most of the sea-birds that frequent New South Wales waters have at various times been observed offshore from vantage points near Botany Bay, or have been found washed up on the beaches. The three-mile stretch of Cronulla Beach is one of the bestpatrolled beaches in Australia for derelict sea-birds. Off Malabar Headland there is usually a large congregation of albatrosses, petrels, skuas, gannets, gulls and terns feeding about the sewer outfall. In winter as many as 100 Giant Petrels, 500 Wandering Albatrosses and many of the smaller albatrosses (notably the Black-browed species) may be observed from the cliffs. The Cape Petrel, various species of prions and four or five kinds of shearwaters (mutton-birds) pass by on their migration flights.

In Botany Bay the Silver Gull is ubiquitous, and both the Pacific Gull and Southern Black-backed (Kelp) Gull appear irregularly. This last-mentioned species was first recorded in Australia (at Botany Bay) in January, 1943. It was seen around the old Cook's River estuary on a number of occasions during the next 12 months, but for nine years afterwards there were no records of it. Since March, 1953, when it re-appeared, it has been observed in three States, and there is little doubt that it has now become established in Australia, as it is in New Zealand, South Africa and South America. Late in 1959 and again in 1960 a pair has successfully nested on Moon Island, off the New South Wales coast at the entrance to Lake Macquarie.

About 10 species of terns have been recorded from Botany Bay, the most noteworthy being the Little Tern, a regular migrant that arrives in October and departs in April. It is the only member of the whole sea-bird group occurring in the area, numbering about 50 species, which breeds within the area's limits. Colonies are known on the sand dunes behind Boat Harbour, along part of Cook's River and particularly on Kingsford-Smith Aerodrome, where banding operations have recently been

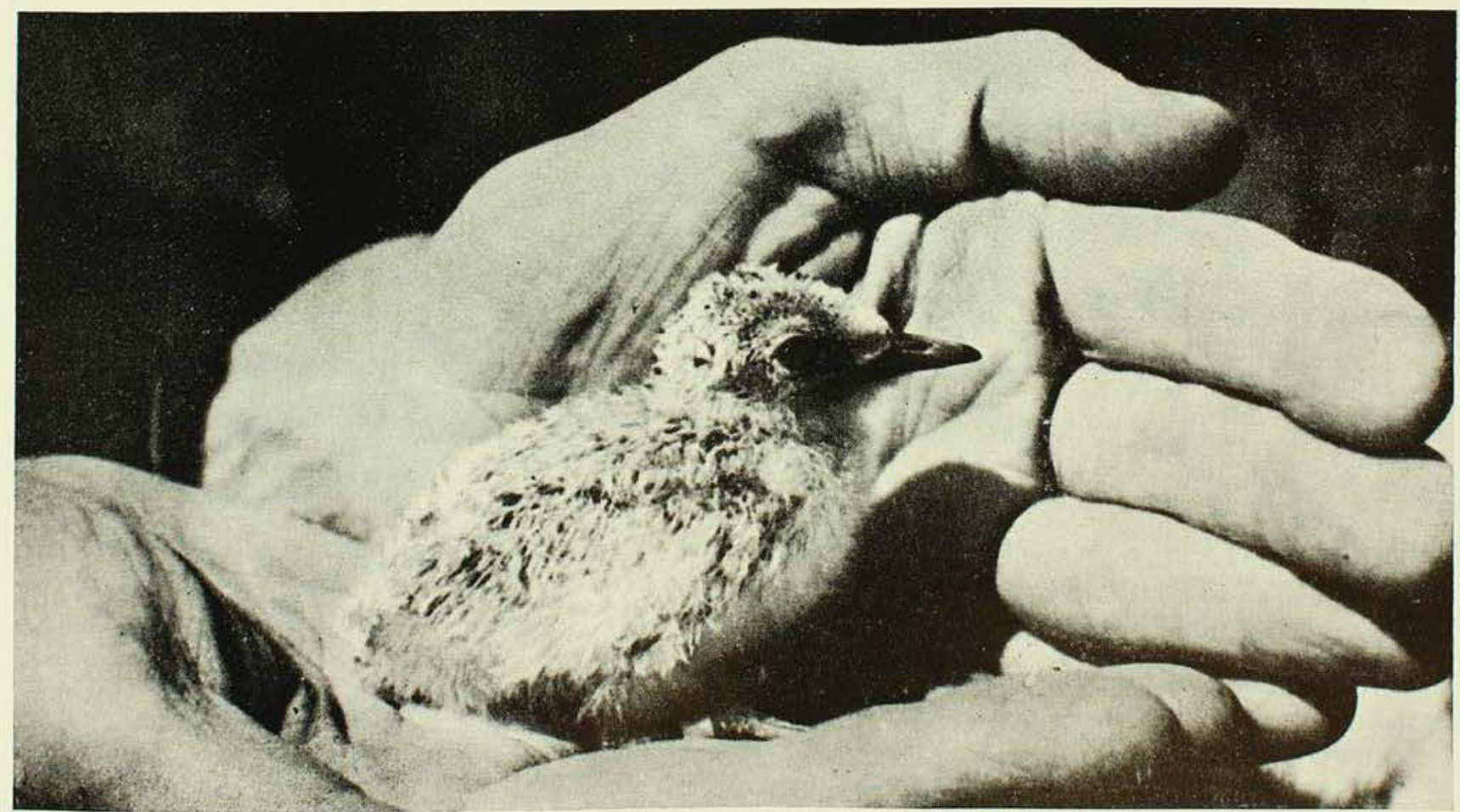

This week-old Little Tern chick has just been banded as part of a study by ornithologists of the migrations of this species. The chick was caught on open sand on the Mascot Aerodrome, in the Botany Bay area. Little Terns, which grow to a length of about 9 in., lay their eggs in slight depressions in open sand. 


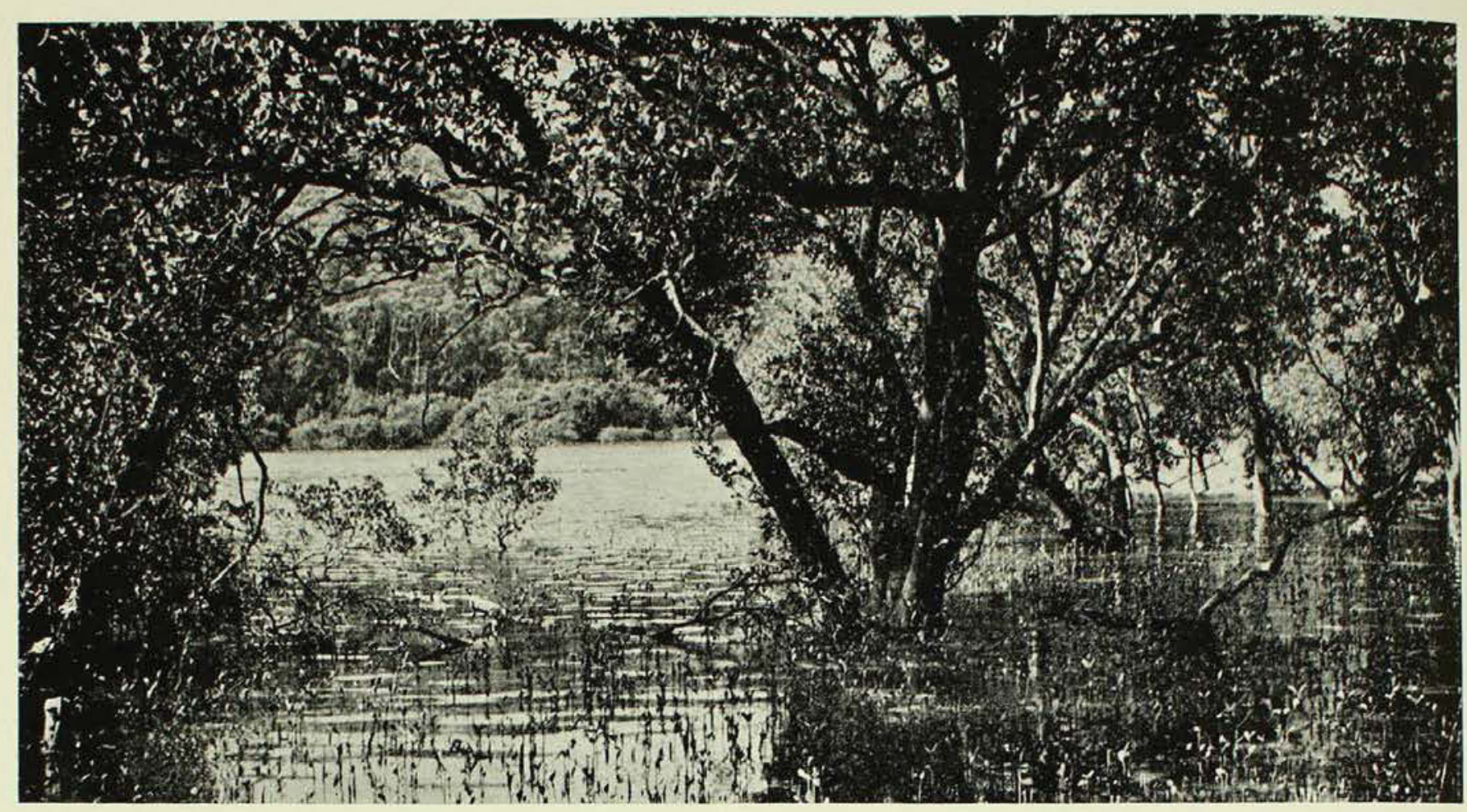

Mangrove trees (above) fringe the shores of most of southern Botany Bay. They provide excellent shelter for many kinds of birds, including the Mangrove Heron (right) Photos.-K. A. Hindwood.

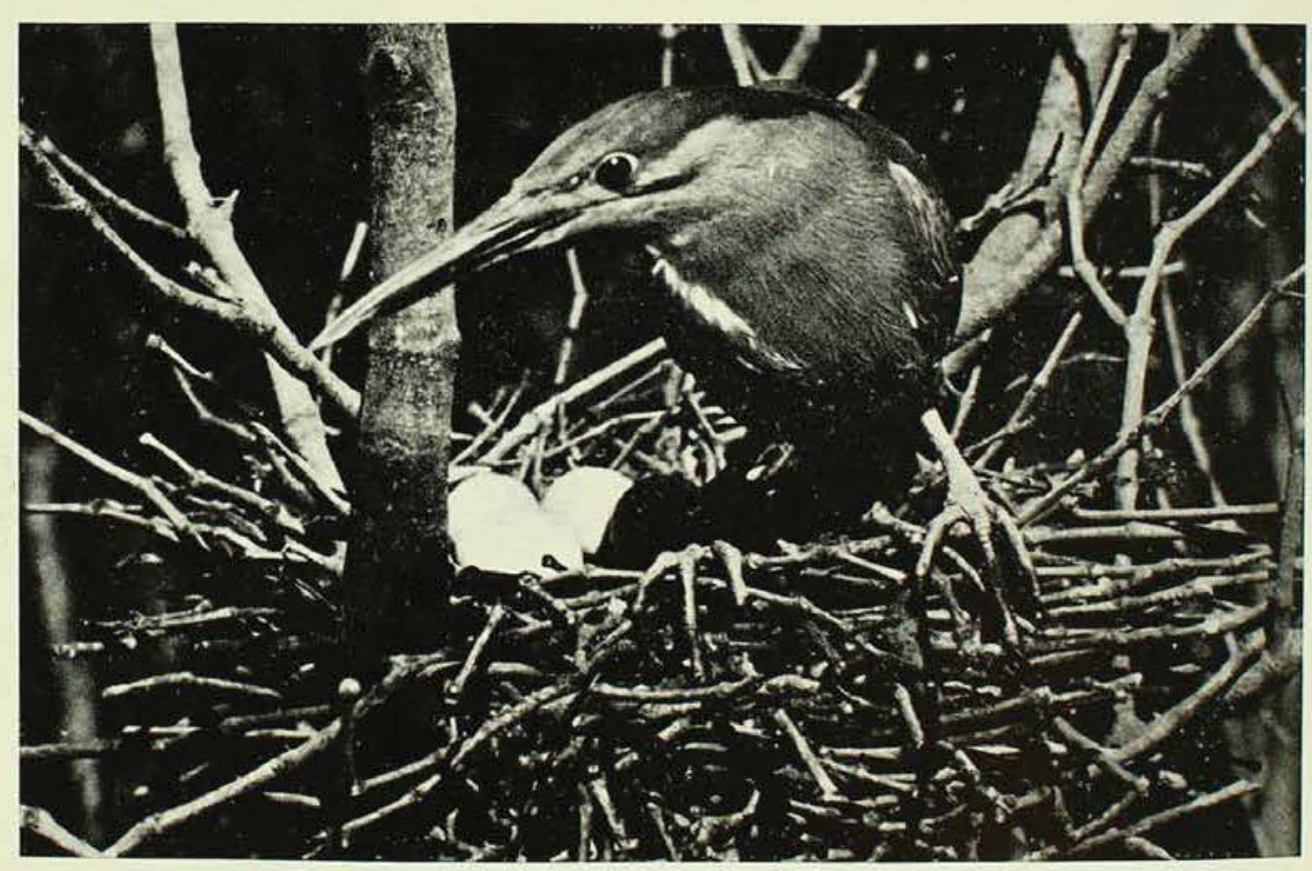

undertaken. These operations may eventually determine the winter quarters of the Australian race of this interesting species.

Swampland is an important habitat, for the bird-life of such places is frequently numerous, both in individuals and species. The Black Swan and various kinds of ducks (four of which occur regularly and breed in the district) accept the relative protection afforded by close settlement. Different species of herons, bitterns, crakes and the larger water-hens forage among the reeds and herbage, and three small passerine birds - the Reed Warbler, Little Grassbird and Fantail-warbler (Tailor-bird) - enliven such places with activity and song.

\section{Fine Songster Still Common}

Around most of southern Botany Bay, in the various inlets, there are still extensive tracts of mangroves, which, together with adjacent samphire flats, provide suitable places for Mangrove Herons, four species of 
cormorants, pelicans, egrets, ibis, spoonbills, the White-fronted Chat and such waders as the Golden Plover and Sharptailed Sandpiper. Even the stately Jabiru has recently been observed there. Mangrove forests provide excellent shelter for many kinds of perching birds, the most conspicuous being the Brown Honeyeater, which, fortunately, is still common in this area. It is a beautiful songster and gives life and vitality to such a habitat, so often regarded by the average citizen as wasteland and the breeding place solely of snakes and mosquitoes. Botany Bay is about the southern range limit of this species in the east.

A good deal of heathland occurs on both the Kurnell and La Perouse Peninsulas, but, except for the Emu-wren, Yellow-winged Honeyeater, Tawny-crowned Honeyeater and an occasional Heath-wren, this type of habitat does not contribute prominently to Botany Bay bird-life.

Forest country is practically confined to localities south of Botany Bay, such as around Woolooware Bay and at Kurnell, where there are small tracts of angophora and eucalypt scrub, clumps of casuarina and much low banksia growth. The Little Wattle-bird may be considered the most conspicuous bird of this habitat, but many other species are resident there also, and numerous others find shelter during migration. In the low undergrowth associated with forest country the smaller groundfrequenting birds forage, breed and live.

However, Botany Bay is perhaps best known ornithologically as a feeding ground for migrant waders, which occur at times in large numbers on tidal flats, shoreline, the reef at Boat Harbour and the estuaries of Cook's and George's Rivers. The tidalooze adjacent to the old estuary of Cook's River has long proved an excellent place to study the habits, movements and numbers of the many types of waders which visit Australia annually, mainly from their breeding grounds in eastern Asia. One species, the Double-banded Dotterel, nests in New Zealand, and good numbers spend the winter in Botany Bay. Four waders (the Spur-winged Plover, Banded Plover, Blackfronted Dotterel and Red-capped Dotterel) are somewhat resident in the area and breed there. Two kinds of oyster-catchers occasionally occur and a further Australianbreeding species, the White-headed Stilt, appears to be re-establishing itself at Botany Bay in small numbers after an apparently lengthy absence.

\section{Habitat Retention Essential}

No fewer than 25 species of waders breeding in eastern Asia have been recorded from Botany Bay. These retain their old-world vernacular names, such as plover, turnstone, snipe, curlew, whimbrel, godwit, sandpiper, tattler, stint, greenshank and sanderling. Although these reach their maximum numbers in summer, many kinds, such as the Bar-tailed Godwit, Red-necked Stint, Curlew Sandpiper, Eastern Curlew and at times the Lesser Knot and Mongolian Dotterel, remain in smaller numbers during the winter. The Sanderling is an interesting species which has returned, for the past 20 years to my knowledge, to the reef and adjacent beach at Boat Harbour, but only in small numbers which have declined gradually; in the past three years no more than one or two have been seen. As this bird is rare anywhere in eastern Australia, this regular migration to Boat Harbour is especially significant. It is hoped these visitations by the Sanderling (which only breeds in Arctic regions) will continue and its numbers again increase.

No doubt the numbers of bird species known from this fascinating area will increase. However, many of those recorded must be regarded as purely accidental, while others have disappeared from the district where they at one time bred or were considered common. Others have become alarmingly rare in recent years. Every effort should be made to retain a suitable portion of each type of habitat in its natural state. so that Botany Bay will still hold its ornithological importance and fascination. 


\section{KOALA \\ MANAGEMENT IN VICTORIA}

By J. McNALLY

Deputy-Director, Fisheries and Game Department, Victoria

THIRTY-FIVE years ago it was widely stated that the koala (Phascolarctos cinereus), one of Australia's most interesting marsupials and the one with the most public appeal, was doomed to extinction. This attractive but relatively defenceless animal was at one time numerous and widespread in Victoria. In the late 1800's, however, epidemic diseases destroyed thousands, and the decline was further hastened by shooting for furs and sport. Large numbers were also destroyed by bush-fires. Strict legal protection was later provided, but bush-fires remain a threat.

As a result of a combination of destructive factors the koala disappeared from many areas, and it was doubtful if it could survive in Victoria outside special reserves. Fortunately, small colonies remained in certain localities, where they are still flourishing. Notable amongst these were parts of Gippsland, the Mornington Peninsula and the Stony Rises in the Western District. The koala might be restricted to such localities at present if the Government had not instituted a major reestablishment programme.

In the early 1920's the Victorian Fisheries and Game Department embarked on a koala management programme, which is continuing. Earlier, koalas had been introduced to Phillip and French Islands, in Western Port Bay, from places on the adjacent Victorian mainland. The koalas found the low coastal Manna Gums on these islands most suitable as food, and their numbers increased rapidly. These island populations have since provided the holding areas for koalas from which surplus animals are transported to restock suitable localities on the mainland of Victoria.

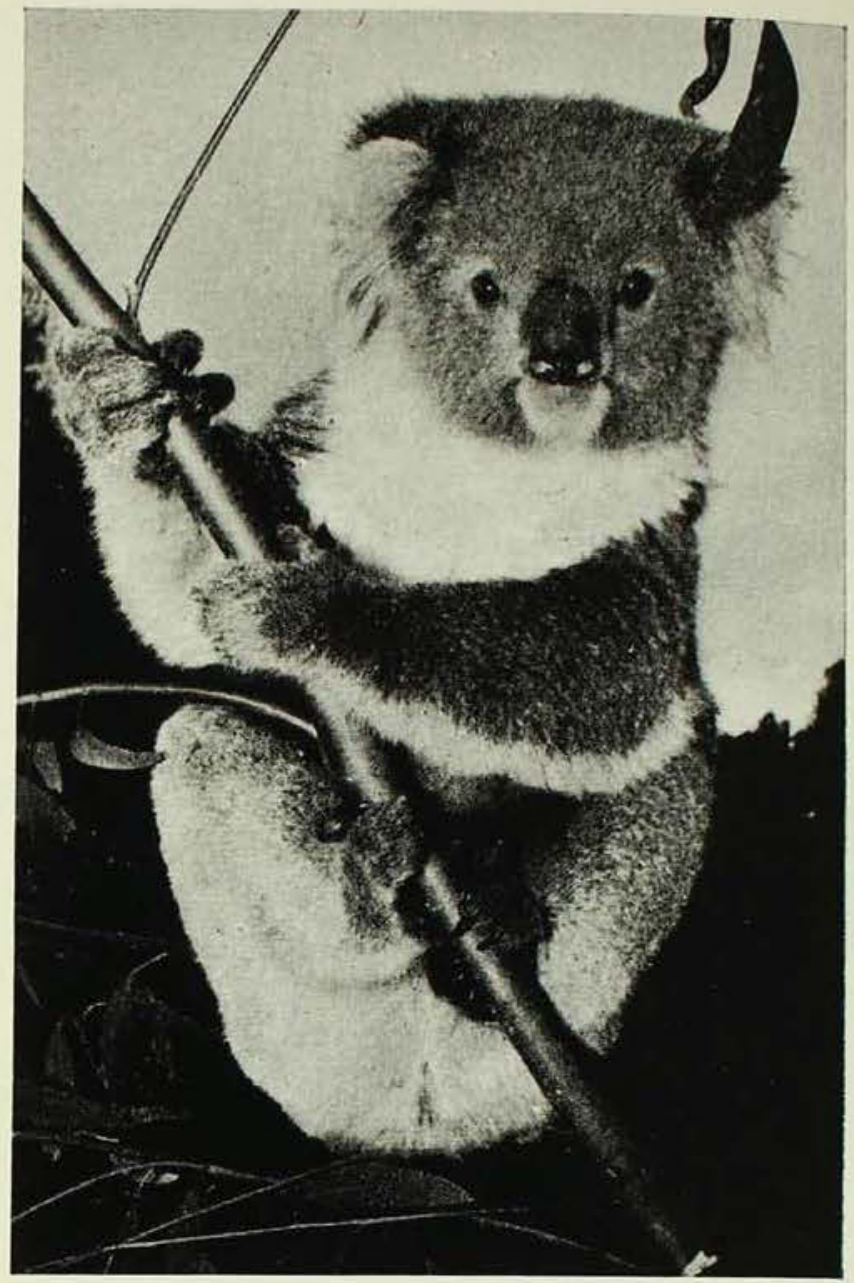

A young koala.

Photo.-Fisheries and Game Department, Victoria.

Eucalypts are the principal and essential food of koalas, and the Manna Gums (Eucalyptus viminalis), which they prefer above other species, will support only a certain number of them on the islands. Officers of the Fisheries and Game Department inspect the islands regularly, and, when the numbers of koalas are found to be too high, the surplus is removed to selected areas on the mainland. These areas must fulfil certain requirements. They must be large and have abundant suitable food trees; freedom from fire-risk, habitatdestruction and alienation are important features. Localities which previously supported large numbers of koalas when they were widespread and flourishing in Victoria receive attention.

\section{7,000 Koalas Liberated}

Since the work commenced, approximately 7,000 koalas have been liberated and more than 50 areas restocked. Major 
liberation sites are the Mornington Peninsula, the Durdidwarrah Water Reserve, Mount Alexander, the Stony Rises, Mount Cole State Forest and Halls Gap in the Grampians. Experimental Red Gum areas are maintained at Goat Island in the Goulburn River at Nagambie, and at Lock Island in the Murray River at Mildura. Fenced sanctuaries, where the public can see koalas at close quarters, are located at Mt. Alexander, Castlemaine, and at Creswick. Koalas are also supplied to the Melbourne Zoological Gardens and to the Sir Colin MacKenzie Sanctuary at Healesville.

Spectacular results have been achieved by the koala restocking activities. However, this is only one aspect of the overall management programme, which includes a detailed study of the biology and ecology of Phascolarctos. Basic research is carried out in conjunction with the liberation work, in which there are many problems that can only be tackled on the basis of scientific study. For example, the koala appears to suffer from a variety of diseases, some of which are peculiar to it. Captive koalas often die from dietary upsets resulting from lack of provision of the essential eucalypt species. An investigation of the enzymes involved in the physiology of digestion of eucalypts would help to prevent deaths.

The management programme also provides an opportunity to study the population dynamics of the koala in the field. A population confined to an island can rapidly outgrow its food supply, and French Island over the years has provided an interesting study. On several occasions since the island was first stocked its koala population increased to such an extent that the Manna Gums were defoliated and many died. As a result of this food shortage the koala numbers rapidly declined. The trees gradually regenerated and the surviving koalas once more began to thrive and multiply. The great majority of koalas have since been removed from French Island, as it has become unsuitable as a holding area because of increased settlement and frequent fires.

The koala is not an easy subject to study in the field. Its arboreal habit often makes it inaccessible, and a trained and experienced six-man team is needed to capture animals without harming them. The

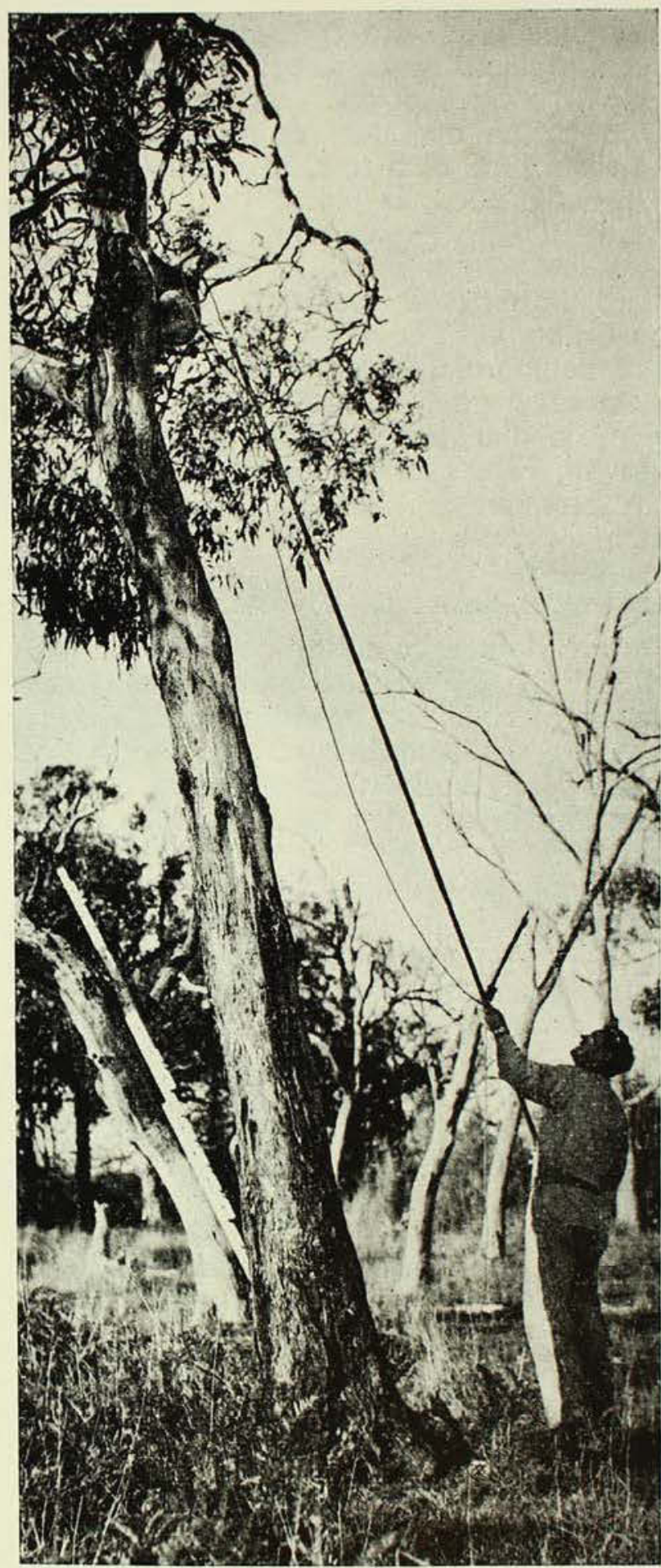

A rope noose, on the end of a long pole, is used to catch koalas. Here, a noose is being placed over a koala's head. The operator pulls on the rope until the animal either descends the tree or is pulled from it to fall into a catching-sheet held by four men, as shown on the next page.

Photo.-Commonwealth News and Information Bureau. 
technique is an old one, but still has not been replaced with a better method. A long pole fitted at one end with a noose is used by an operator, on a ladder or an adjacent limb of a tree, to catch the koala. When the noose is placed over the koala's head it is prevented from tightening completely by a check in the rope. At this stage the operator drops the pole and pulls on the rope. The animal may descend the tree voluntarily, but if it doesn't tension is maintained on the rope until it releases its grip on the tree and drops toward the ground, where its fall is broken by a circular catching-sheet held out by four men.

\section{Important Information Obtained}

In the course of collection and liberation, all animals are weighed and measured, and details of condition, breeding state and any diseases are recorded. This information, when finally correlated, will make a major contribution to the knowledge of koala biology.

During the weighing and measuring procedure the koala usually objects strongly. Its powerful shoulder muscles and long hooked claws, together with a crushing bite, make it a formidable subject. It is not vicious by nature - far from it-but fright at the unusual treatment causes it to react defensively. The operators have to take every precaution when handling koalas, and at least four strong men are needed.

Transportation and liberation in the new area are routine and present few problems. The koalas are transported in special crates containing two compartments, in each of which two koalas travel. A standard truck-load is eight crates, containing 32 animals, but this varies according to the sexes and ages of the koalas. The adult males are aggressive and two cannot be put together in one compartment. Usually a male and female are crated together, or a female with its young.

In most cases the Manna Gums at the liberation sites are very different from the low, stunted coastal trees which form the habitat on the holding islands. The mountain Manna Gums are tall, heavybutted trees, which take some negotiating by animals not used to them. The koalas quickly accommodate themselves to the new
This koala refused to descend a tree and was pulled from it. Photo. - Commonwealth
News and Information Bureau.

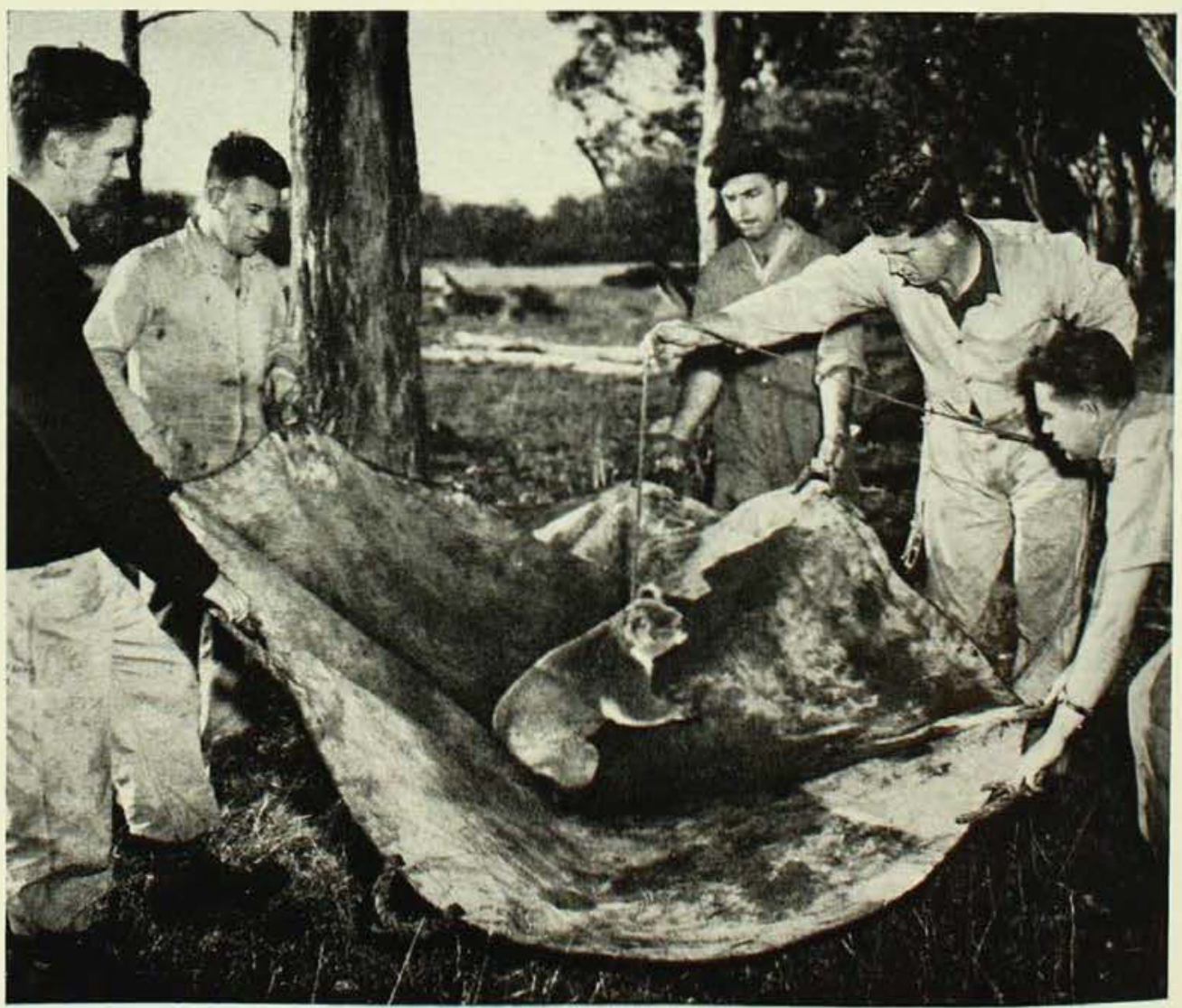




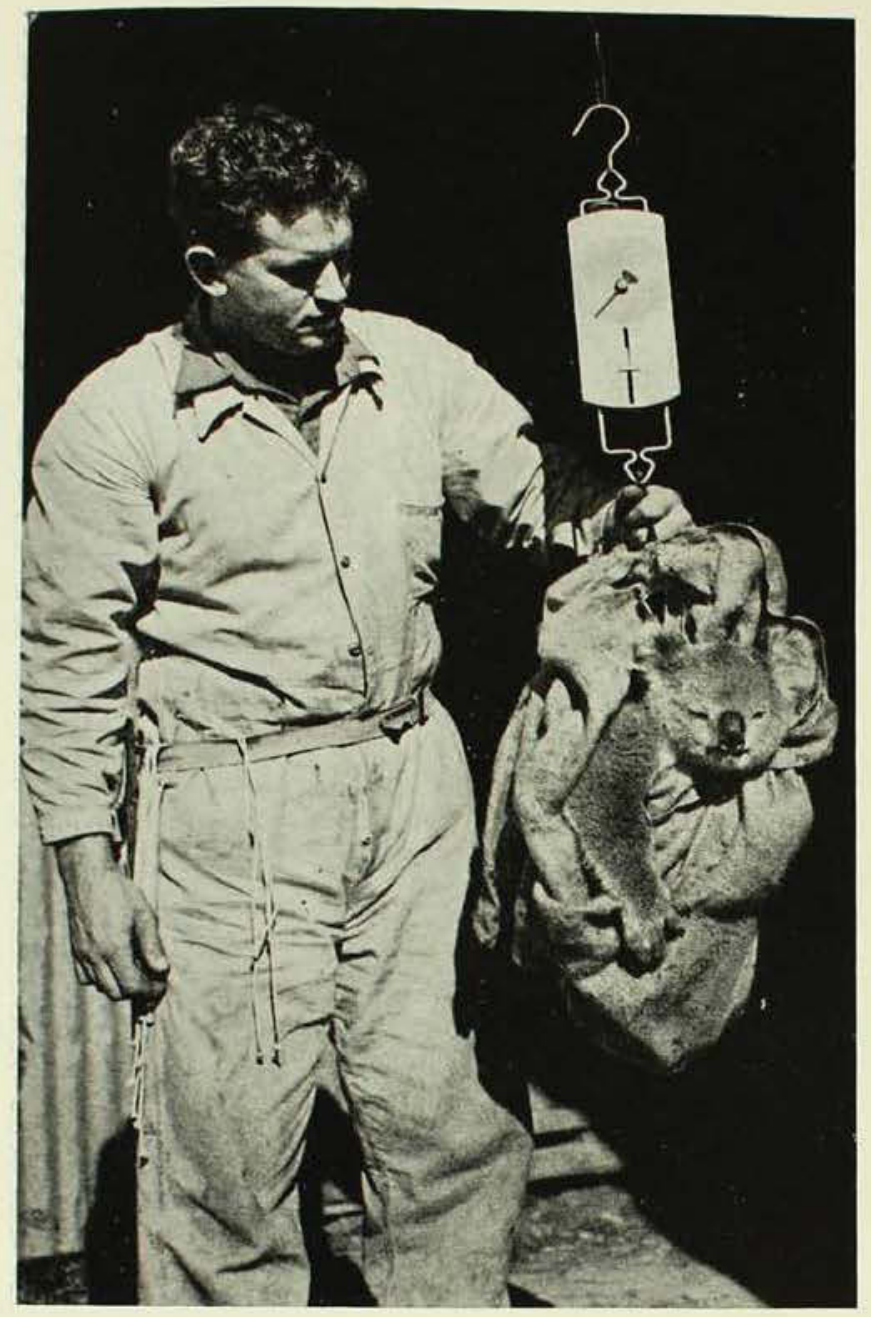

A koala being weighed in a bag. All koalas caught and liberated are weighed and measured, and details of their general condition are recorded.

Photo.-Commonwealth News and Information Bureau.

environment and usually lose no time in ascending to the heights - much higher than they have ever been before.

Re-establishment is being carried out according to a detailed, long-range plan in which a number of State organizations are co-operating. The distribution of Manna Gums has been investigated with the help of the Forests Commission of Victoria, and a list of potential liberation sites has been prepared. The present policy is that these sites should have abundant permanent stands of suitable food trees and large areas enabling the koalas to spread out from the liberation points and re-populate the sites in the course of time. Every effort is made to ensure that the selected sites are as free as possible from fire risk and are served by an efficient fire-fighting organization. State forests meet the requirements as regards suitability for koala colonisation, and many of the major liberations have been made in these areas.

\section{Fire Danger}

Although every precaution is taken in advance to see that the fire risk is minimal, there is always the possibility that fire will destroy stands of timber. For this reason, every effort has been made to select liberation sites in widely scattered areas of the State, so that if fire occurs in one area it will not ruin the re-establishment plan.

As a result of the rapid development of Victoria, Phillip Island and French Island are becoming closely settled and the koala habitat is being reduced to such an extent that these islands are no longer suitable as major holding areas for koalas. Other unsettled coastal islands are being investigated to locate new holding areas. Chinaman Island, also in Western Port Bay, is already a permanent holding reserve, and the adjacent Quail Island, which was at one time a holding area, may be suitable for replanting and development.

The Fisheries and Game Department receives many offers and requests from private individuals, municipal councils, etc., for koalas to be released in small areas where suitable food trees have been established. Quite apart from the difficulties of supervision, it is not practicable to accede to these requests, as koalas roam widely at night and would soon disperse from such areas.

The koala re-establishment programme is one of the most successful animal management projects undertaken here or elsewhere in recent years. The status of the koala has been raised in a relatively short time from the verge of extinction to a sound level. It may be confidently stated that the future of these animals in Victoria is assured and that they will continue to increase under wise management.

\section{Back Numbers of Magazine Wanted}

A member of the Museum staff wishes to buy five back copies of The Australian Museum Magazine - Nos. 1 and 5 of Vol. I and Nos. 1. 7 and 10 of Vol. II. Any reader who can make these available is asked to ring Mr. Mackay at the Museum, BM 6954. 


\section{DANGEROUS MARINE ANIMALS}

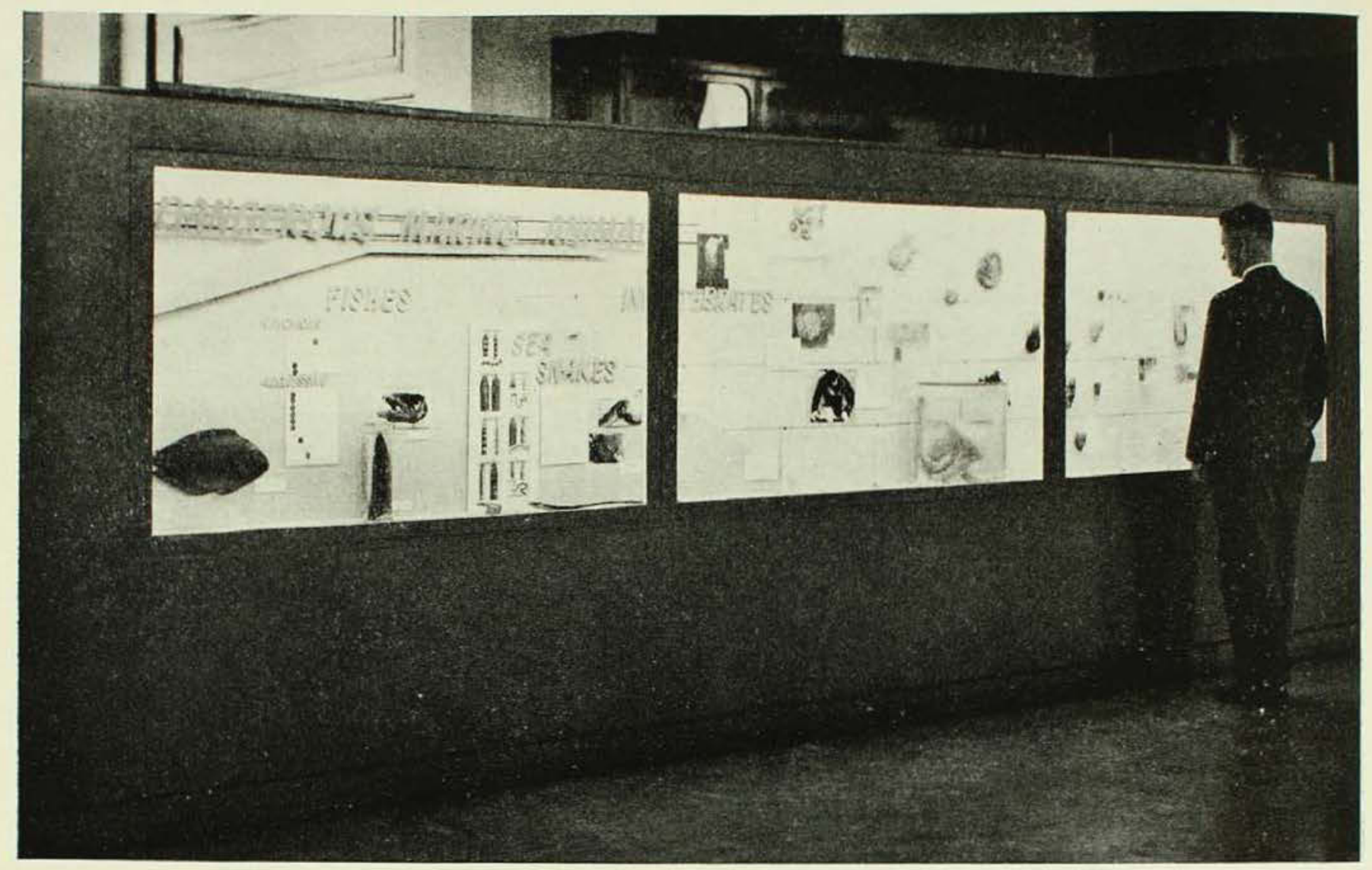

The hazards of dangerous marine creatures were discussed at the Australian Museum by members of the Scientific Section of the International Convention on Life Saving Techniques, held in Sydney last March. A special exhibit of dangerous sea animals (illustrated above) was installed in the public galleries of the Museum, and will continue until the end of June.

At the discussions, each group of savage or venomous animals was dealt with by a specialist on the Museum staff who showed how the various species could be recognised and where they occurred in nature. Sea-snakes, sharks, stingrays, aggressive and stinging fishes, venomous molluscs, deadly jellyfishes and other harmful invertebrates were considered. Cases of attacks on, or harm to, humans were described by medical practitioners who had attended victims, and first-aid and medical treatment of injuries were discussed.

Apart from members of the Museum staff, participants in the symposium (the first of its kind held in Sydney) included Surgeon Rear-Admiral L. Lockwood, R.A.N., who had witnessed a fatality from box-jellyfish stinging; Commander Batterham, R.A.N., who, when diving, had had a number of brushes with dangerous marine creatures; Mr. J. R. Kinghorn, who discussed bites from sea-snakes; Dr. V. M. Coppleson, author of "Shark Attack"; Mr. N. Gorshenin, who explained how the numbers of sharks off Sydney beaches had been reduced by meshing; Dr. P. K. L. Phleps and Dr. R. Endean, who discussed stonefishes; Dr. S. Wiener, who has developed stonefish anti-venene; Dr. J. R. Pacy, who has treated catfish and stingray injuries, and $\mathrm{Mr}$. B. Ewers, who gave an account of parasitic worms transmitted through molluscs. Remarkable slides of jellyfishes, their stinging mechanisms. and the effects they cause were shown and explained by Drs. Kingston, R. V. Southcott, J. H. Barnes and T. J. Hansen.

The speakers have prepared illustrated papers and bibliographies on their special subjects. Thus. much original material has been added to that already brought together from scattered published records, and it is anticipated that a useful illustrated volume will be published by the Post-graduate Committee in Medicine of the University of Sydney, which organized the session under the auspices of the Post-graduate Medical Foundation.-Gilbert P. Whitley. 


\section{A Remarkable Parasite of the Long-fingered Bat}

AONGST the interesting parasites of bats are those of the streblid genus Ascodipteron, a genus recorded from Queensland, the East Indies, New Guinea and Central Africa. These flies are remarkable for the change of form undergone by the female after she has attached herself to the host.

On emergence from the pupal cases both sexes are winged; the female has large labellar teeth, but these are small in the male. After mating, the female seeks out a bat (as far as is known only the genus Miniopteris, the long-fingered bat, is parasitized), settles at the base of its ear and makes an incision in the host tissues. She gradually works her way more deeply into the tissues at the base of the ear, casts her wings and legs and eventually becomes embedded in the flesh of the bat with only the apex of her abdomen protruding.

\section{Flask-shaped Sac}

In this protected situation her abdomen becomes enlarged, eventually enveloping her head and thorax. The female fly thus ends up as a flask-shaped sac, with the head and thorax well hidden within the enlarged abdomen. Such extreme changes or form in an adult insect are exceptional.

Ascodipteron is believed to be larviparous, the extrusion of the larva being facilitated by the fact that the apex of the

The top picture shows a female Ascodipteron fly, removed from a bat, with its head and thorax enveloped by its enlarged abdomen. The knob-like lower end of the fly is the apex of the abdomen, all that protrudes when the insect is embedded in the base of a bat's ear. Below: Head of a Miniopteris bat, showing a female Ascodipteron (arrowed) embedded in tissue at the base of the ear.

Photos.-Howard Hughes. female's abdomen is exposed; this exposure also facilitates respiration. Of all the Streblidae, the females of Ascodipteron show the greatest change of form associated with a parasitic life. The finer details of the life history of Ascodipteron have not yet been worked out.
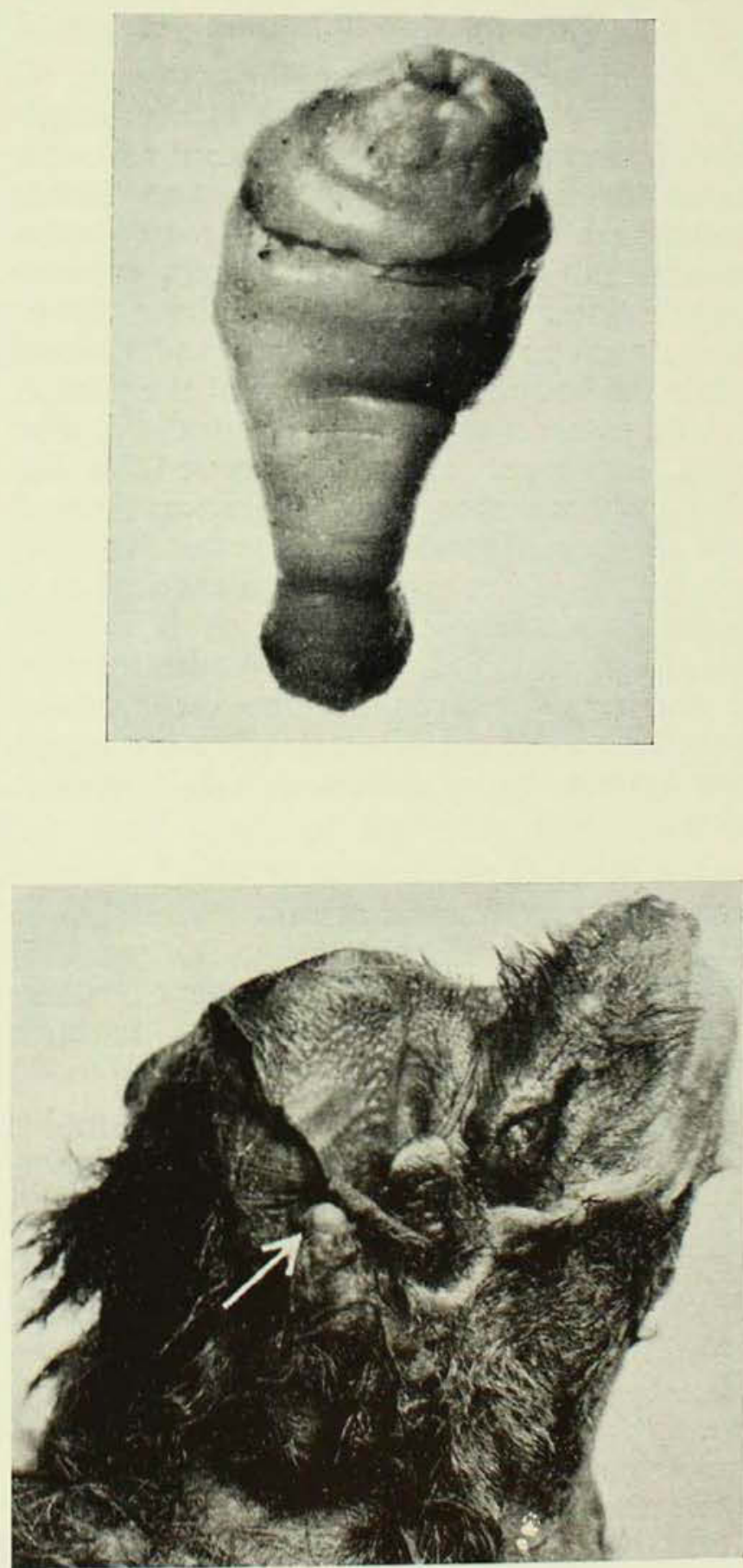


\section{THE EVOLUTION AND RADIATION OF MAMMALS}

By B. J. MARLOW

$\mathrm{M}^{2}$

AMMALS, the fossil history of which is fairly well known, evolved from a group of reptiles called Synapsids, or "mammal-like reptiles," which arose during the Permian period about 200 million years ago and flourished for 20 million years until the end of the Triassic period.

At first these animals were rather lizardlike, but as time progressed several features, especially in the skull, teeth and limbs, underwent remarkable changes towards the mammalian condition. The teeth became differentiated into groups for different functions, such as incisors, canines and molars, while the body was lifted clear of the ground by the rotation of the limbs beneath it. The most important changes occurred in the skull, where a secondary palate was formed and the seven bones of the lower jaw that are typical of the reptiles were reduced to a single bone, the dentary, which is characteristic of mammals. Some of these bones in the reptilian jaws became incorporated into the middle ear of mammals to form the two extra auditory ossicles which mammals alone possess.

The other characteristics of major importance among mammals are the possession of hair and the production of milk, but it is not known at what stage, in the transition from reptile to mammal, these features appeared.

Living mammals fall into three major groups-monotremes or egg-laying mammals, marsupials or pouched mammals, and placentals which retain the embryo for a relatively long gestation period. These three groups developed from a diversity of primitive mammals which arose during the Mesozoic period and the history of which is poorly known because of lack of adequate fossil material. The monotremes probably evolved from a separate group, the docodonts, which show the interesting retention of one of the additional bones of the lower jaw lodged in a groove on the dentary. The marsupials and placentals evolved from an important group, the pantotheres, and are now known to have existed together since their origin in the Cretaceous period of North America, although it was once believed that the placentals had been derived from the marsupials. These Cretaceous marsupials were allied to the present-day American opossums, while the placentals were remotely related to present-day insectivores, such as shrews and moles.

\section{Evolution of Mammals In South America}

Both the early marsupials and placentals migrated into South America from the north and began to branch out into several distinct groups. During the Eocene period, when the main evolution of placentals occurred, South America was isolated from the rest of the world and further entry of placentals was prevented. The primitive American opossums gave rise to two other groups of marsupials, the extinct Borhyaenids, which were large carnivorous mammals, and the Caenolestids, which are small insectivorous marsupials similar to the marsupial mice of Australia.

The main groups of placentals in South America were the South American monkeys, guinea-pig like rodents, true ant-eaters, sloths and armadillos. In addition, several groups of peculiar hoofed mammals also flourished, but became extinct in the Pleistocene period, when a land connection was re-established with North America. The fossils of some of these animals, particularly a giant form called Toxodon, were discovered by Darwin during the voyage of the Beagle. Once the route to the north had been reopened, a complicated movement of mammals occurred in both directions. Some of the marsupials, ant-eaters and rodents 
migrated north, and true carnivores, such as cats, dogs and raccoons, and modern hoofed mammals, such as primitive horses, pigs, camels and deer, entered South America from the north.

\section{Mammals In Australia}

All the three major groups of mammals occur in Australia, but, when compared with other parts of the world, the placentals are poorly represented.

The monotremes, which embrace only the platypus and echidnas, are confined to the Australasian region. These animals show a remarkable combination of primitive and specialised features, but unfortunately their fossil record is extremely meagre. They have many reptilian features - such as the retention of the egg-laying habit and the structure of shoulder girdle, skull and spinal column-which indicate that they are the most primitive of living mammals, but superimposed on these are such specialisations as the beak-like snout, absence of teeth in the adult stage and limbs modified for digging.

The most primitive Australian marsupials are the dasyurids, a family which contains native cats and marsupial mice. These animals have several features in common with the South American marsupials, and are probably the basic stock from which the other Australian marsupials evolved. The remaining Australian marsupials belong to two widely different groups - the bandicoots, which have some features in common with the dasyurids, and the large super-family the Phalangeroidea, which contains not only the phalangers, or Australian possums, but also the kangaroos and wombats.

All marsupials differ from the placentals in the following respects: There is normally no true placenta, or after-birth, for the nourishment of the embryo in the uterus, and, in consequence, the gestation period is normally short and the foetus is relatively undeveloped at birth. It crawls into the pouch unaided, becomes attached to one of the teats and there continues its development until it has grown sufficiently to fend for itself. Unlike the placentals, only one tooth in each half of each jaw is replaced among the marsupials, which thus have virtually only one set of teeth throughout their lives. These differences are not to be considered as primitive features, but rather as fundamental differences in structure which arose when both groups separated from the basic stock that gave rise to each branch.

Only two groups of terrestrial placentals and three aquatic forms are found in Australia. These are rodents and bats on the one hand, and seals, sea-cows and whales on the other.

\section{The Evolutionary History Of Australian Marsupials}

As in the case of South America, Australia was separated from the main land-mass of the world. Here, too, a great radiation of marsupials occurred, but on this occasion no placentals were present in the early stages. This separation took place at the end of the Cretaceous period, when only marsupials and primitive placentals existed in the world. The fossil record of marsupials in Australia is tantalisingly poor, the earliest known form being a fossil possum, Wynyardia, from the Miocene period of Tasmania.

The route whereby marsupials entered Australia is still uncertain. It was formerly suggested that they came down through south-east Asia before the land-masses separated, but there are no fossil marsupials in Asia to support this theory. There are sorne fossil marsupials from Europe which are allied to the American opossums, but there is no definite explanation of how they arrived there. It has been shown that the flora and fauna of South America, South Africa, Australia and New Zealand have many features in common. It has been suggested that these regions were once united with Antarctica to form a southern continent known as Gondwanaland and that it was via this continent that the marsupials entered Australia. The isolation of Australia at the end of the Cretaceous period is probably responsible for the survival of both the monotremes and marsupials here today. No competition was experienced from any placentals until the arrival of rodents from south-east Asia by fortuitous means, which probably involved raft transportation on floating debris.

During the Pleistocene period many large forms of marsupials evolved in Australia, including giant kangaroos (Palorchestes), 


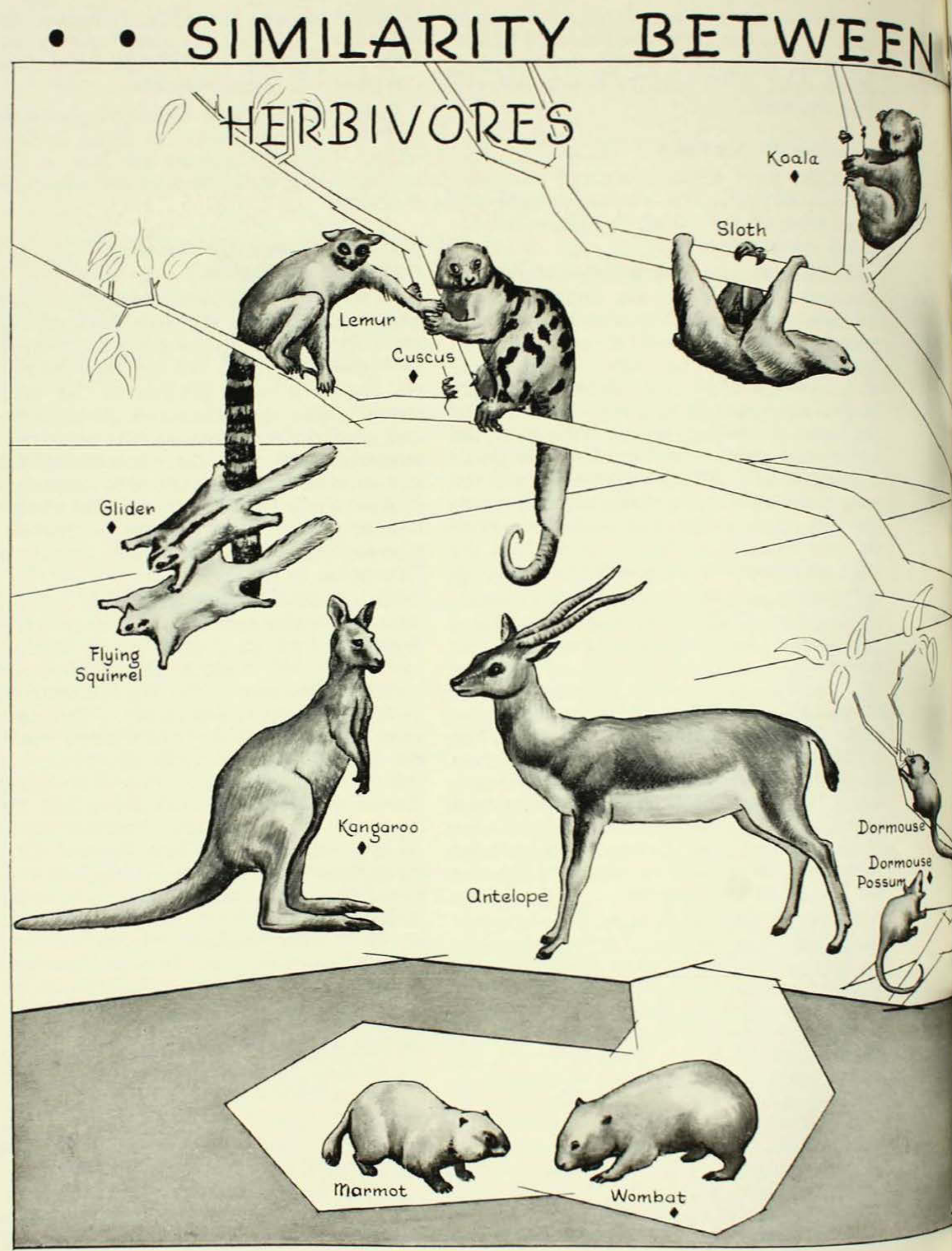




\section{MARSUPIALS \& PLACENTALS}

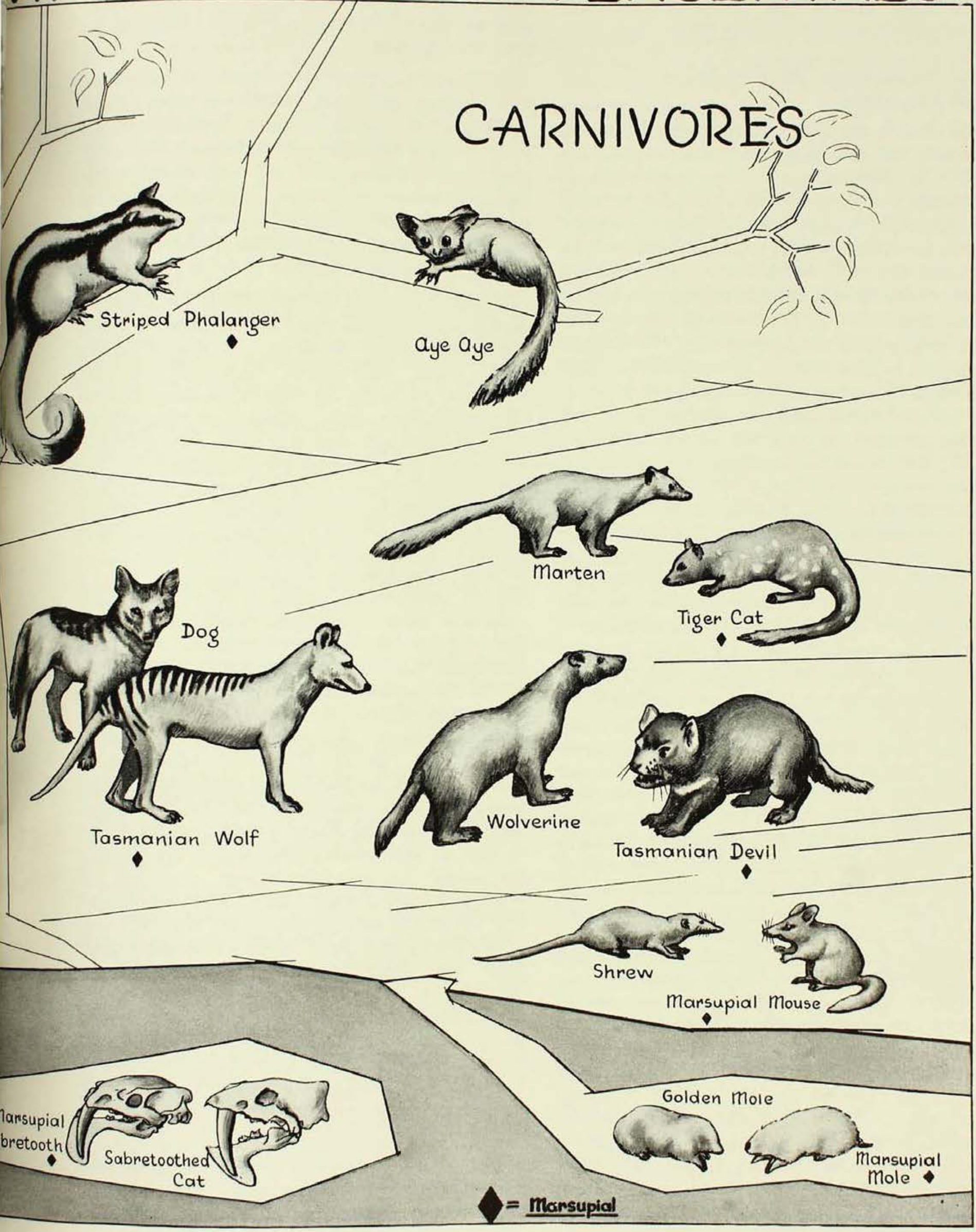


which were about $9 \mathrm{ft}$. high, huge wombats such as Diprotodon, which was the size of a rhınoceros, and a large possum, with huge shearing teeth, called Thylacoleo.

\section{The Convergence Of Marsupials And Placentais}

In his book "The Origin of Species", Darwin showed that evolution may come about by the selection by the environment of changes or mutations which arise fortuitously in the reproductive cells of animals, since those mutations which are beneficial will be perpetuated while those that are harmful will prevent the animal from surviving to pass on these characters to its offspring. A remarkable example of the operation of this natural selection is seen when a comparison is made between the marsupials, which have evolved in isolated areas, and the placentals, which arose in other parts of the world. Animals which live in similar environments and which have comparable ways of life tend to resemble each other to a remarkable degree, both in external appearance and in the way their bodies function. This similarity in unrelated animals is called convergence. Marsupials and placentals provide the best example, as is shown in the illustration.

The way in which animals obtain a living, or the niches that they occupy, may be considered broadly on a basis of diet, and the first group are the herbivores (mammals which feed on plants). The earliest herbivores were browsers which fed on the leaves and shoots of shrubs and bushes, but with the advent of grasses in the Miocene period true grazing mammals were able to evolve. The placental mammals which fill these niches today are the deer, antelopes, sheep and other ruminants which have special modifications in their digestive systems that allow food to be regurgitated after the indigestible cellulose, with which plant cells are covered, has been broken down by special bacteria in the stomach. They are normally fast-running animals, the limbs of which have become elongated by raising the body on to the extreme tips of the toes. Among marsupials, the same niche is occupied by the kangaroos and wallabies. These have a similar digestive physiology, but only their hind limbs are elongated and they have a bounding gait instead of running on "all fours". Kangaroos probably evolved from the tree-living possum group, and the tree kangaroos of north Queensland and New Guinea have become secondarily adapted to an arboreal life.

There is no exact counterpart of this niche among placentals, since the ruminants have such specialised limbs that none of them have been able to become arboreal. Among those placentals which are well adapted for life in trees are the lemurs, a primitive group of monkeys, and squirrels; the marsupials which correspond to these are the cuscuses and possums of Australia.

Some arboreal herbivores have become highly specialised, and among these are the sloths of South America. These animals, which are leaf-eaters, hang from the branches of trees by means of long curved claws on their feet. They are sluggish in their movements and are relatively defenceless, but are protectively coloured by the green algae which grow in grooves on their hair. This niche is filled in Australia by the koala, which is really a tailless possum, and is also a specialised, slow-moving, leaf-eater, with well developed claws used in climbing.

There exist in North America, Eurasia and Africa groups of specialised squirrels which have a loose membrane along their flanks by means of which they are able to glide long distances from tree to tree. In Australia, too, this adaptation has arisen among the glider possums, which have similar habits to the flying squirrels. Other small arboreal rodents of the Old World are the dormice, which are mixed feeders living in shrubs and bushes and which are closely paralleled by the dormouse possums of Australia, since they, too, feed on insects and blossoms among flowering shrubs. An extension of this type of niche is that occupied by the Australian honey mouse (Tarsipes), for which there is no exact counterpart among the placentals, as it is a nectar-feeder with a long brush-tipped tongue which can be inserted into flowers. This type of feeding is more reminiscent of certain fruit bats or, among birds, of honeyeaters.

Yet another peculiar herbivorous marsupial without counterpart among the placentals is the curious pig-footed bandicoot 
(Chaeropus ecaudatus), which is probably now extinct in Australia. This animal lived in the open plains and had a remarkable modification of its feet so that, of the original five toes, only two remained functional on the forefoot and only one behind. It has been suggested that this feature was correlated with a running gait, but there is little information on the biology of this species.

An important group of burrowing herbivorous placentals are the marmots and gophers, large rodents of North America and Eurasia, which build extensive warrens in open grassland or in rocky mountainous regions. The wombats of Australia resemble these animals not only in their habits but also in their outward form and in the structure of their teeth and skulls.

\section{Convergence In Flesh-eaters}

Examples of convergence also exist among flesh-eating, or carnivorous, marsupials and placentals. Wild dogs are running carnivores which hunt either singly or in groups. They are indigenous to all parts of the world except Madagascar and Australasia, for the dingo here was probably introduced by the aborigines. The rare thylacine, or Tasmanian wolf, which formerly existed on the mainland, fills this niche among Australian marsupials, its similarity to the dogs being remarkable.

Another important group of ground-living placental carnivores are certain weasels, such as the badgers and wolverines which are found in North America and Eurasia. A similar way of life is shown by the Tasmanian devil.

No marsupial in Australia has converged towards the cats ; those marsupials known as tiger cats and native cats are more comparable with the arboreal martens and other weasels. In South America, however, some of the large extinct Borhyaenids became very cat-like - to such an extent that a sabretoothed marsupial, Thylacosmilus, arose which was a close parallel of the placental sabre-toothed cats of North America. One of the main reasons for the survival of marsupials in South America would appear to be that they played the role of carnivores there in the absence of placental competition, for it was not until the land connection was re-established with the north during the Pleistocene period that placental carnivores were able to enter.

An insectivorous diet is merely an extension of a carnivorous mode of living, and the small insect-eating marsupial mice of Australia correspond to the mouse-like placentals, the shrews, while some bandicoots resemble, both in appearance and habits, certain large primitive insectivores in the West Indies, such as Solenodon. The small hopping marsupial mouse Antechinomys is an extreme example of adaptation in Australia. Like so many other plains-living mammals, its hind limbs are elongated, and its way of life is similar to the elephantshrews of Africa, which have the same modification.

Some remarkable examples of convergence exist among the insectivorous placentals and marsupials. In New Guinea, there is a striped possum, Dactylonax palpator, that feeds mainly on the larvae of woodboring beetles which it extracts from their tunnels by means of a long thin finger on its fore-foot. In Madagascar is a primitive monkey called the Aye-Aye, which has a similar modification of its hand and which feeds in the same manner. The convergence between these two animals is to be found more in their habits than in their external appearance.

The most extraordinary example of convergence, both in appearance and habits, exists between two burrowing insectivorous mammals. These are the placental golden moles of South Africa and the marsupial mole of Central Australia. Both animals have tubular bodies, short erect fur, reduced eyes and external ears and enlarged digging fore-feet. They dig shallow burrows in sandy soil and feed on various invertebrates, especially earthworms and insects. Although these animals are not closely related, they have come to resemble each other to a remarkable degree because of the operation of natural selection on a similar mode of life in comparable environments.

\section{Niches Unfilled By Marsupials}

Although marsupials have radiated widely, there are certain niches which they have not occupied. In South America is a carnivorous aquatic marsupial, Chironectes, 
which lives in rivers and feeds on freshwater crustacea and the larvae of aquatic insects. There is no marsupial in Australia which lives in this manner, and here this niche is filled by two indigenous nonmarsupials, the platypus and the water rat.

No herbivorous aquatic marsupials exist which would fill the niche occupied by beavers or musk rats, and in Australia this position is filled by an indigenous rodent, the swamp rat (Rattus lutreolus). In general, Australian rodents seem to have filled most of the niches normally occupied by this group in other parts of the world, and these again show convergence. The Australian hopping mice (Notomys) are similar in both appearance and habits to the kangaroo mice of North America and the jerboas of the Old World, although they are not closely related.

Similarly, no marsupial has evolved the power of true flight, which, among mammals, is restricted to the bats. These animals are well represented here, since water barriers present no obstacle to their dispersa!. This is also true of marine mammals such as seals, sea-cows and whales, all of which are represented in Australia, but the way of life of which has not been copied by marsupials.

This remarkable convergence towards the form and habits of placentals which has occurred among the marsupials during their isolation in South America and Australasia is one of the most important pieces of evidence to support Darwin's theory that evolution has come about by the influence of naturai selection operating on chance mutations which arise in the heredity of living organisms.

\section{[Illustration by B. P. Bertram.]}

\section{Lord Howe Island Corals}

Following a coral-collecting trip to Lord Howe Island, Dr. D. Squires, of the American Museum of Natural History, New York, recently spent a week examining the Australian Museum's extensive collection of corals from that locality. Dr. Squires intends to publish his research on the little-known coral fauna of the island, the location of the most southerly of coral reefs. This publication should be of great value to Australian marine zoologists. Dr. Squires is an associate of Professor John W. Wells, of Cornell University, U.S.A., a world authority on the true, or reef-building, coral growths.

\section{CORROBOREE FROG}

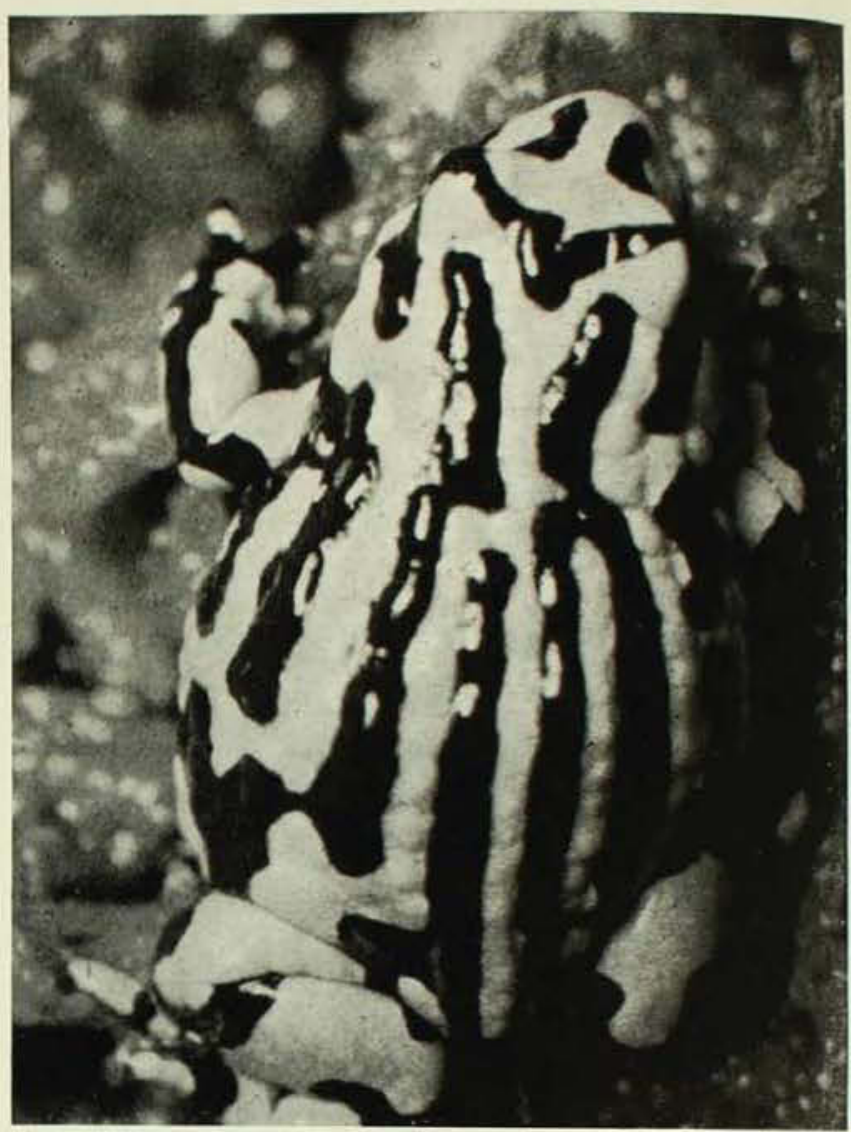

Thirty live Corroboree Frogs (Pseudophryne corroboree), one of which is illustrated above, were displayed at the Australian Museum last January. This was the first time that Corroboree Frogs had ever been exhibited at the Museum.

These frogs, which have so far been found only in the Australian Alps, inhabit regions 4,001) $\mathrm{ft}$. and more above sea-level. They average only an inch in length, and are black with yellow stripes. Their name comes from the resemblance their colour-pattern bears to the way in which some Aborigines painted themselves for corroborees.

The specimens displayed were collected at Mount Kosciusko by Mr. R. Cox, of Croydon Park, Sydney, who gave them to the Museum. Twelve of them were later sent to Professor J. Moore, of the American Museum of Natural History, New York. It was Professor Moore who. while working in Australia in 1953, first described the Corroboree Frog from a single preserved specimen in the Australian Museum's collection.

There are many interesting features about the life-history of the Corroboree Frog, for its whole way of life is adapted to living in high alpine areas covered by snow for part of the year.

An account of the Corroboree Frog will be found in an illustrated booklet, "The Frogs of New South Wales", by Harold G. Cogger, to be published by the Museum shortly. This handbook will consist of two sections; one will deal with the general biology of the frogs of New South Wales, while the other will be a guide to the identification of all the species which have been recorded from this State. 


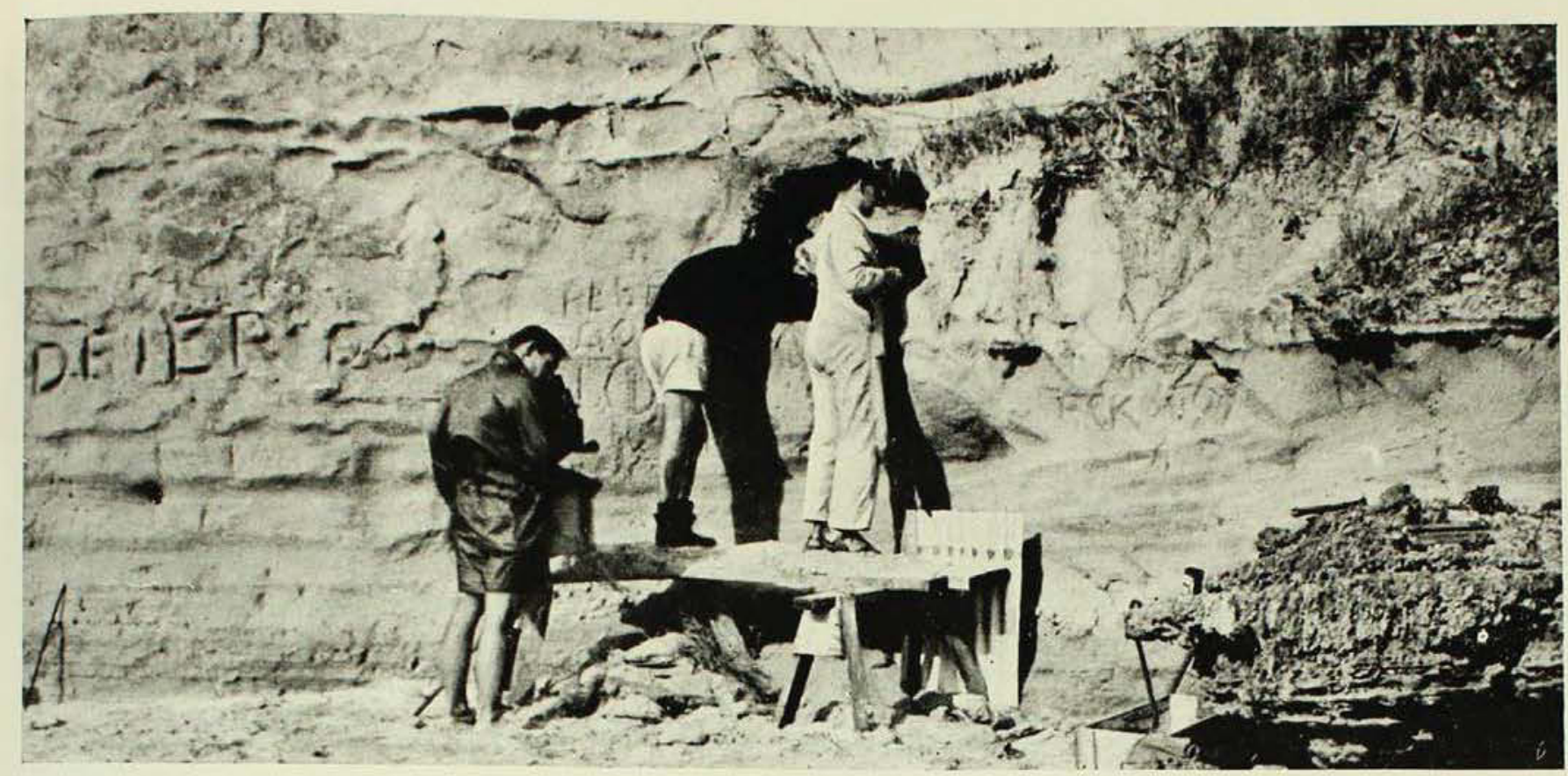

Broken pieces of the complete shell of an extinct horned turtle, Meiolania, being taken from a cliff base at Ned's Beach. Lord Howe Island, a few months ago. This remarkable find was made by Mr. Ray Missen (centre), a meteorological officer on the island. With him are Mr. J. Whistler (left), of the Lord Howe Island Board, and Mr. J. Kirby, a local resident.

Photo.-Elizabeth C. Pope.

\section{Turtles of the Past}

By H. O. FLETCHER

$T^{2}$ remarkablerm a most interesting and fromarke group of reptiles, not only from a palaeontological point of view but also as one of the most peculiar and isolated groups of vertebrate animals.

The earliest known turtles lived and flourished about 180 million years ago during the latter part of the Triassic geological period. They appear suddenly in the geological record as well-preserved fossils in various parts of Europe, and even in these so-called primitive forms their skeletal structure and general appearance are practically identical with the turtles we know so well today. In fact, as one author has stated, ". . were they now living they would attract no special attention from the ordinary observer and but little from the naturalist".

The Order Chelonia of the Class Reptilia, to which turtles and tortoises belong, is the most characteristic and narrowiy-defined group among the reptiles, and although it has the longest-known geological history it has undergone only slight evolutionary changes since its inception. The exact origin of turtles is uncertain, as there is no trace of any transitional forms prior to Triassic times and their early line of ancestry is therefore mainly a matter of speculation. It is generally considered that they were derived from the cotylosaurs, a group of primitive reptiles and the basal stock from which other reptilian groups arose. The specialized nature of the first known turtles indicates that it is almost certainly in the late Palaeozoic period that we must look for forerunners of the group.

\section{Box-like Armour}

The earliest Triassic turtles possessed the extraordinary, but most effective, protective box-like armour so characteristic of living turtles. The shell is readily divisible into two parts - an upper, or dorsal, known as the carapace, and a lower, or ventral, 
called the plastron. The bony plates of the carapace are formed mainly by a flattening and broadening of the neural spines of the turtle's backbone, or vertebrae. These form a middle row of plates on the carapace, and attached to them on either side is a lateral series of plates formed by a flattening and expansion of the ribs. A circle of marginal plates is also developed, and the whole is united together to form a rigid shelly covering which protects the body of the turtle. The carapace is attached to the plastron, but the shell is widely open in front and behind so that a turtle can withdraw its head, neck, limbs and tail within the armour to obtain safety from almost any form of attack.

Turtles are the only vertebrate animals which do not have a flexible backbone; it is firmly fused for part of its length to the carapace of the box-like shell or armour.

Safe from attack, the early turtles were no doubt lazily content with their amphibious mode of life, and doubiless spent most of their time crawling in low-lying marshes or swimming in the sea. They lived in an ideal and variable environment, in which there was a plentiful food supply. On no occasion was there real need for further specialisation for any evolutionary changes to enable survival. Turtles have always lived a somewhat conservative, and even uneventful, existence. As a result, the group has survived through a long period of geological time to the present day, and is still a flourishing one. This is in contrast to some other large reptilian groups which, as a result of over-specialization, have become extinct.

\section{Oldest Group Of Turtles}

The oldest group of turtles is the sub. order Amphichelydia, to which belong not only the primitive forms of the Upper Triassic period but also many of the dominant types which came into existence during the following Jurassic and Creta. ceous times. They all possessed the characteristic features of the later turtles and their shell structure was essentially the same. There were some differences, how. ever, and in a genus known as Trias. sochelys small teeth were developed on the palate and the marginal bones of the jaws were provided with rudimentary teeth. In all other turtles teeth are absent and their function is very effectively provided by a strong and bird-like horny beak.

At the beginning of the Tertiary era, about 60 million years ago, turtles of the Amphichelydia became reduced in numbers, and only one or two forms lingered on for a short time before becom. ing extinct. The only surviving Family of the suborder, the Meiolaniidae, which comprise the giant horned turtles, persisted
The shell of Meiolania before it was shattered while being removed from the cliff base.

Photo. - Elizabeth C.

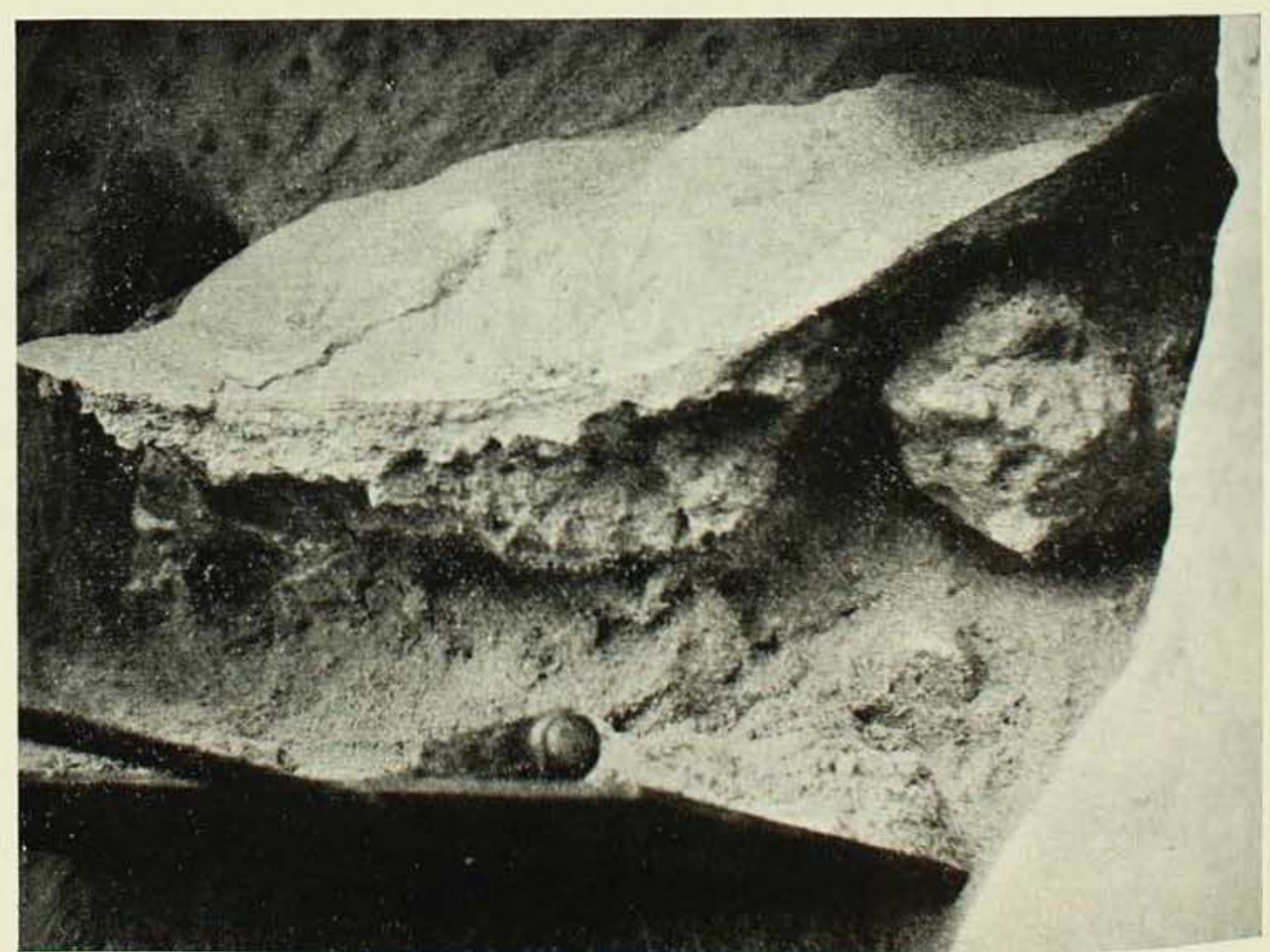


through Tertiary times and became extinct in the Pleistocene period, only some thousands of years ago. The oldest form of the Meiolaniidae is Niolamia, recorded from rocks of doubtful Cretaceous or Eocene age in Patagonia. A slightly smaller form from Eocene rocks in Argentina was described in 1937 as Crossochelys.

No trace of Meiolaniids was found in post-Eocene Tertiary rocks until their appearance in supposed Pliocene deposits in a deep-lead at Gulgong, New South Wales. The form of horned turtle in these deposits is known as Meiolania. It has also been collected from Pleistocene sediments at Coolah, New South Wales, the Darling Downs, Queensland, and Lord Howe Island and Walpole Island, about 100 miles southeast of New Caledonia.

The early discovered fossil remains of the various genera of the Meiolaniidae were mainly fragmentary, and the Family has been placed by authors in both the other suborders of the Chelonia, the Pleurodira and the Cryptodira. A former Director of the Australian Museum, the late Charles Anderson, after an examination of fairly good fossil material, considered that it presented several noteworthy features which linked it with the Amphichelydia. He stated that it was a "relict" form of the suborder which, after becoming extinct in other parts of the world, found its last home in several continents of the southern hemisphere.

Horned turtles were unable to withdraw their heads or necks within the shelter of the carapace in either a vertical or a horizontal plane as is the case in the Pleurodira and the Cryptodira. Their limbs resembled those of river and marsh turtles, and it was generally considered that in all probability Meiolania was a strong swimmer even though it lacked the special adaptations found in most turtles which have achieved a marine existence. Some authors, however, are of the opinion that it lived almost entirely on land, although they think it may have inhabited estuaries or have been shore-living and could make short sea journeys.

In 1930. Dr. Anderson described some fossil limb-bones of Meiolania from Lord Howe Island. He said the structure of the skeleton and its heavily-armoured condition strongly indicated that it was essentially a

\section{Museum Director's Overseas Tour}

Dr. J. W. Evans, Director of the Australian Museum, who has been awarded a UNESCO Fellowship to study museums overseas, left Sydney on March 29 for Honolulu, accompanied by Mrs. Evans. After visiting several centres in the United States Dr. and Mrs. Evans will travel to Europe where they will visit museums in the United Kingdom, Sweden, Holland, Switzerland and France. They will also attend the International Entomological Congress in Vienna in August and, before returning to Sydney early in October, will spend a month in Tokyo, where Dr. Evans will be the Australian representative at a UNESCO-sponsored Museums Conference.

terrestrial turtle and that the limb bones were adapted for progression on land.

\section{Important Find}

Several months ago Mr. Ray Missen, an officer of the Meteorological Station on Lord Howe Island, while searching for the fossil remains of Meiolania discovered what appeared to be a complete carapace and plastron partly projecting from a soft, sandy deposit of Pleistocene age near the base of a cliff at Ned's Beach. After partial excavation it was obvious that the specimen was a complete shell, with limb-bones, of Meiolania.

Realising the importance of this find, Mr. Missen and Miss Elizabeth Pope, a Curator at the Australian Museum, who happened to be on the island, began the task of completing the excavation of the shell and trying to remove it. A series of photographs was taken while the large specimen was gradually being uncovered and before the final attempt at its removal. Unfortunately, storm waves which had reached the base of the cliff the night before had softened the sandstone matrix. When the base on which the shell rested (and it was of considerable thickness) was raised it collapsed and completely shattered the specimen. The innumerable small fragments are being forwarded to the Museum by $\mathrm{Mr}$. Missen, and it is hoped that in time they can be put together so that the shell will be restored to its original shape. 
Ned's Beach, Lord Howe Island, where the Meiolania shell was found.

Photo. - Elizabeth C.

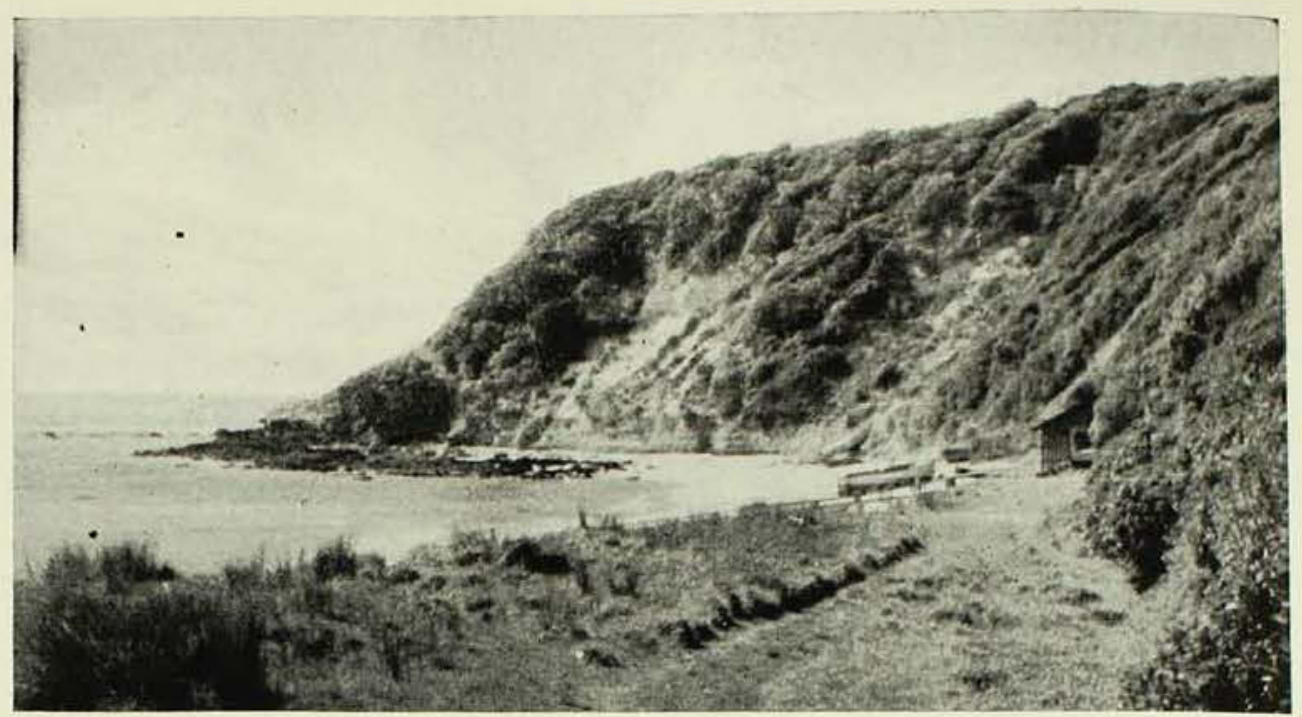

Any information that will be derived from this important discovery will be due solely to the enthusiasm of Mr. Missen, who not only discovered the specimen but devoted much time to its excavation.

The horned turtles of the Family Meiolaniidae have frequently been used as one of the lines of evidence of a southern, more-orless direct, land connection between South America and the Australian continent. The value of this evidence depends almost entirely on whether these turtles were essentially terrestrial creatures or whether they were equally at home in the sea and even moderately good swimmers. It would appear from the specimen at Lord Howe Island that the shell was not heavily armoured and, in fact, it was comparatively thin and flattened. This would indicate that the turtle was perhaps a fairly good swimmer, even though its limb-bones do not support this suggestion.

The two remaining suborders of the Chelonia, the Pleurodira and the Cryptodira, were flourishing groups and were well established at the end of the Cretaceous geological period. In the Pleurodira the head and neck were bent laterally in a horizontal plane and came to rest under an eave-like extension of the shell structure when the turtle wished to protect itself. On the other hand, turtles of the Cryptodira withdrew their heads into the protection of the shell by an S-shaped curvature of the neck in a vertical plane.

Fossil remains of turtles of the Pleurodira are rare in Tertiary sediments, and very few forms are still living. The existing forms are virtually restricted to the southern hemisphere, being distributed in South America, Southern India, Africa, Madagascar, New Guinea and Australia.

The suborder Cryptodira includes most of the living tortoises and turtles. The tortoises which are not known to have occurred earlier than the Eocene period have welldeveloped feet and claws and are still a flourishing group in most continents.

\section{Giant Turtles}

It is generally considered that turtles during Triassic and Jurassic times led an amphibious existence, but by the beginning of the Cretaceous period certain groups had rapidly become adapted to a life which was completely marine; their swimming ability had increased and they were successfully established as sea-living creatures. In the early Tertiary period marine turtles had increased considerably and, as one would expect, certain evolutionary changes had taken place with their change from an amphibious mode of life. Some of the early marine cryptodires, such as Archelon and Protostega, which inhabited the Cretaceous seas, attained great size and were at least 12 $\mathrm{ft}$. in length and weighed about three tons.

Increase in size sometimes accompanies a change of environment. This happened with marine turtles, but, because of the buoyancy of the water, added weight is not a handicap.

On the other hand, however, there were also evolutionary changes which lessened weight and reduced bone tissue and the bony 
A present-day "luth"

or turtle. These may reach a length of $8 \mathrm{ft}$. and a weight of about 1,150 lb., but their ancestral forms were much larger.

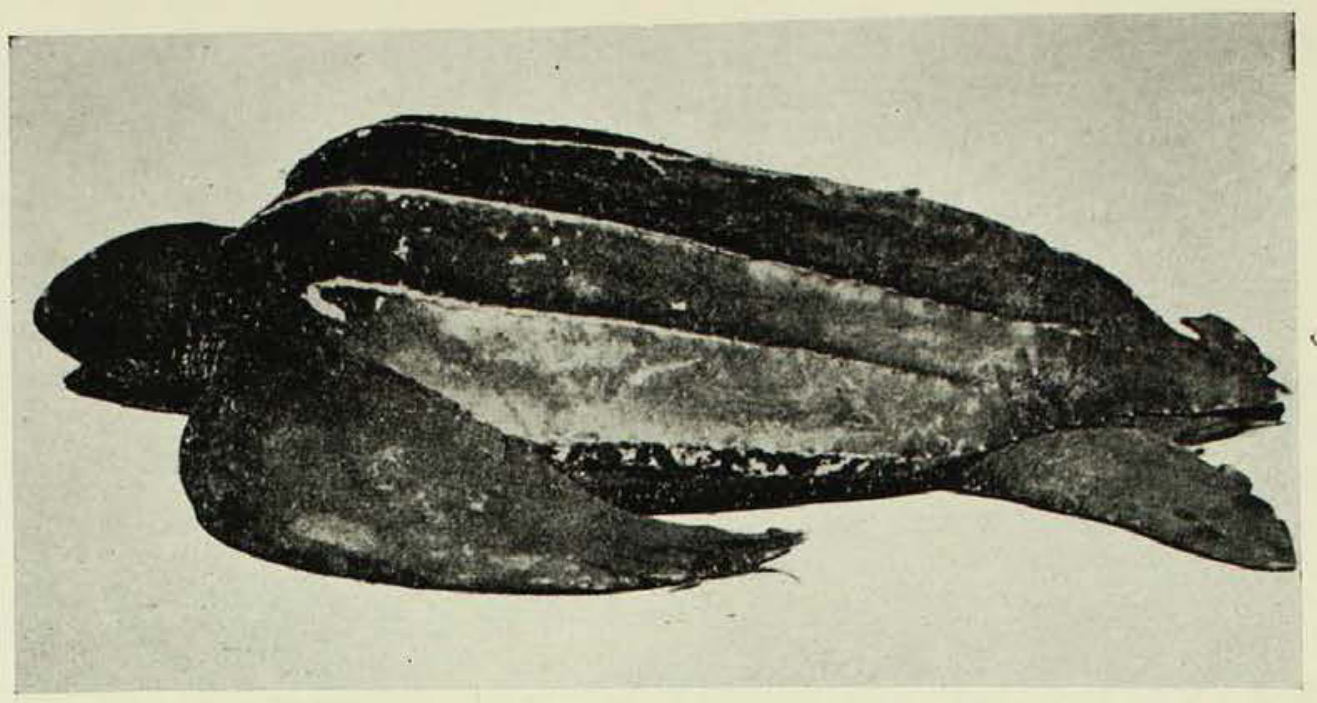

plates of the shell armour. The shell itself also became generally more flattened as an aid in swimming. The proximal bones of the limbs developed into short and powerful bones, while the digits became elongated and broadened to form swimming flippers. These changes are the most noteworthy in the evolution of turtles. They took place early in the geological history of the group, and since Cretaceous times there have been little or no major structural modifications. An Upper Cretaceous genus known as Chelone is represented in present-day seas by the Green or Edible Turtle (Chelone mydas), and it is an excellent example of the general conservatism of the group through a long period of geological history.

The living "luth" or "leather-back" turtle may attain a total length of at least $8 \mathrm{ft}$. and a weight of about $1,150 \mathrm{lbs}$., but its ancestral forms of the early and middle Tertiary were much larger. This marine turtle's shell-armour has always been so much reduced in its bony elements that it has been suggested it is the most primitive group of turtles. Fossil evidence does not support this, however, as remains of "leather-backs" are not found in any of the Mesozoic rocks.

Many of the marine turtles are fast and powerful swimmers, though one might expect that their general shape and the oarlike movements of their limbs would make them awkward.

\section{Queensland Find}

The fossil remains of an early type of giant marine turtle were found in Lower Creta- ceous rocks at Sylvania Station, 20 miles west of Hughenden, Queensland. This turtle is represented by portions of the left shoulder girdle, incomplete limb-bones and part of a plastron. These remains were described in 1915 by $\mathrm{H}$. Longman, at one time Director of the Queensland Museum, as Cratochelone berneyi, and from the bone proportions the turtle was estimated to have been at least $12 \mathrm{ft}$. in length. It is possible that in the future further fossil remains of this interesting giant marine turtle will be found and more information gained regarding its structural features and phylogeny.

A small marine turtle, less than $1 \mathrm{ft}$. in length, has also been collected from Lower Cretaceous rocks on the Flinders River, Queensland. This turtle is known only from an anterior portion of a carapace and plastron. It was described by Professor Owen in 1882 as Notochelys costata, but has since been referred to the genus Notochelone.

\section{Norwegian Scientist's Visit}

Mr. I. Vigeland, a Norwegian scientist visiting Australia to do research into growths of marine invertebrates which foul ship hulls, has spent much time studying at the Australian Museum. The Museum has extensive collections of a particular group, the Bryozoa, which are especially prominent among fouling organisms. Mr. Vigeland comes from the Zoological Museum of Oslo and the Biological Station of Espegrend, Bergen. His visit to Australia was sponsored by the C.S.I.R.O. Division of Fisheries and Oceanography. 
A typical mayfly (mature male), showing the lengthened forelegs characteristic of the males of certain species. Slightly enlarged.

After Comstock.

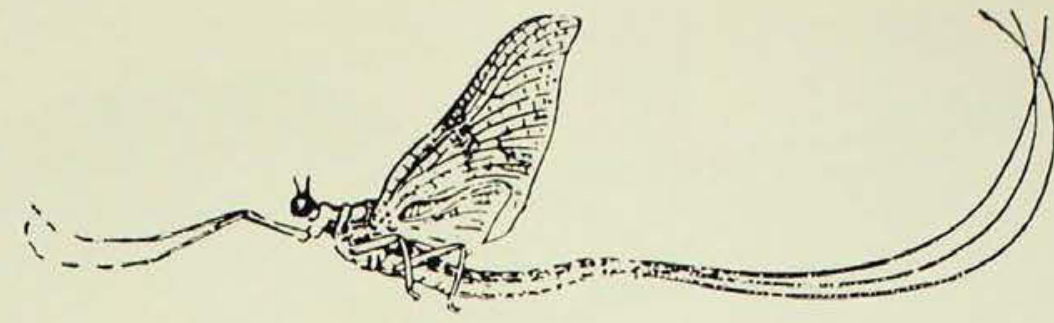

\section{Mayflies}

\section{By DAVID K. McALPINE}

$\mathrm{M}^{\mathrm{Y}}$

AYFLIES are not familiar to most people, as they do not generally occur in gardens nor do they interfere with crops of any kind. They are, nevertheless, quite common in suitable environments, such as stream margins, and are intensely interesting insects. They constitute one of the major groups or orders of insects, Ephemeroptera.

A typical mayfly is a slender, delicately built insect with large, transparent forewings, much shorter hindwings and two or three long filaments on the tail end. This insect may be found clinging to reeds or foliage overhanging a stream during the heat of the day. At dusk or when the sky is overcast male mayflies may be seen flying in swarms over the water. Their flight is weak and they do not progress very noticeably in the air, but tend to hover or move up and down. Their wings are clearly not adapted for swift forward flight, nor can they hover as efficiently as hover-flies and hawk-moths.

When a female mayfly approaches the swarming males pairing takes place immediately. Some kinds of mayflies have to lay their eggs within a very short time, as they only live an hour or two in the winged stage. Others live for a few days, or even weeks, and several hundred eggs are laid over a longer period.

\section{Leaf-like Gills}

The eggs fall into the water, where they may adhere to stones, weed or other submerged objects. The larvae or nymphs which hatch from the eggs lead a wholly aquatic life, and can swim and crawl actively. The larvae of most species are somewhat like silverfish in appearance, with a pair of long filamentous antennae and three pairs of tail filaments, as in the adults. Along each side of the abdomen is a series of leaf-like gills which are waved almost continuously. Thus, a current of water is constantly passing over them. It has been proved that, while in some kinds the gills definitely have a respiratory function, there are species in which no more oxygen is absorbed through the gill surface than through the rest of the body surface. In the latter case the gills probably aid respiration by maintaining a current of water over the body surface.

The larvae live in a variety of different habitats, but are confined to fresh and usually clean water. The majority are to be found in running water, but during droughts, when small creeks cease flowing, they may survive in stagnant pools, even when the water is discoloured by decaying leaves. Some species habitually live in swamps, and I have seen larvae in pools which were strongly discoloured with a permanent suspension of yellow clay. There are larvae which burrow into river beds and may only be obtained by dredging. Most larvae are vegetable feeders, many obtaining microscopic plants from the detritus or sludge on the creek bed.

As the larva grows it sheds its cuticle, or skin, periodically, as this part is incapable of growth. Mayflies moult their skin more frequently than do other insects; one species does so at least 23 times. In the early stages the wing buds appear as projecting lobes on the thorax, which increase in size with each moult. 
After the larva has attained its full size it leaves the water and crawls on to a stone or the stem of a water plant. Here the insect emerges from the larval skin and the wings are fully expanded. Though it can now fly a short distance it has not yet reached the adult state. The wings are dull and almost opaque, and the mature body colour and structure are not fully developed. The insect at this stage is called a subimago. The subimago, which is quiescent if undisturbed, remains clinging to a bank or some foliage until ready to cast its final skin. The subimaginal stage may last from a few minutes to 24 hours, after which the final moult occurs and the mature insect, or imago, flies off. The entire life cycle may take one to three years, depending on the species. Most of this time is occupied in the aquatic larval state.

Mayflies are unique among insects in having two fully winged stages. All other insects have no further moult after attaining the flying stage. It has been suggested that these two stages are characteristic of the most ancient winged insects, and have been retained only in mayflies among present-day insects. Another ancient trait of mayflies is their inability to fold the wings along the body. The wings can only be held vertically over the body or spread flat, the former being the normal resting position.

Among the earliest known fossil insects there was abundance of such forms, as evidenced by their invariably stiffly spread wings. At present the vast majority of winged insects (wing-flexing insects) habitually fold their wings along their bodies when at rest, and only the mayflies and dragonflies (non-wing-flexing insects) cannot do so. Mayflies have been found as very ancient fossils, though they are not as ancient as the more highly evolved cockroaches.

Mayflies are not the only insects which take no food after reaching maturity. They are. however, the only insects which fill their entire gut with air so that it increases their buoyancy in flight. Air is taken in through the mouth, and the stomach is converted into a kind of storage balloon.

\section{Undiscovered Species}

Many kinds of Australian mayflies are now known, but most of these are from the south-east of the continent. Though the number of species is undoubtedly greatest on the well-watered east coast there must be many yet to be discovered in Australia.
The larvae of three kinds of mayflies: a free-swimming form (left), a rock-dwelling form (centre), with two gills more highly magnified, and a burrowing form. All much enlarged.

After Tillyard.
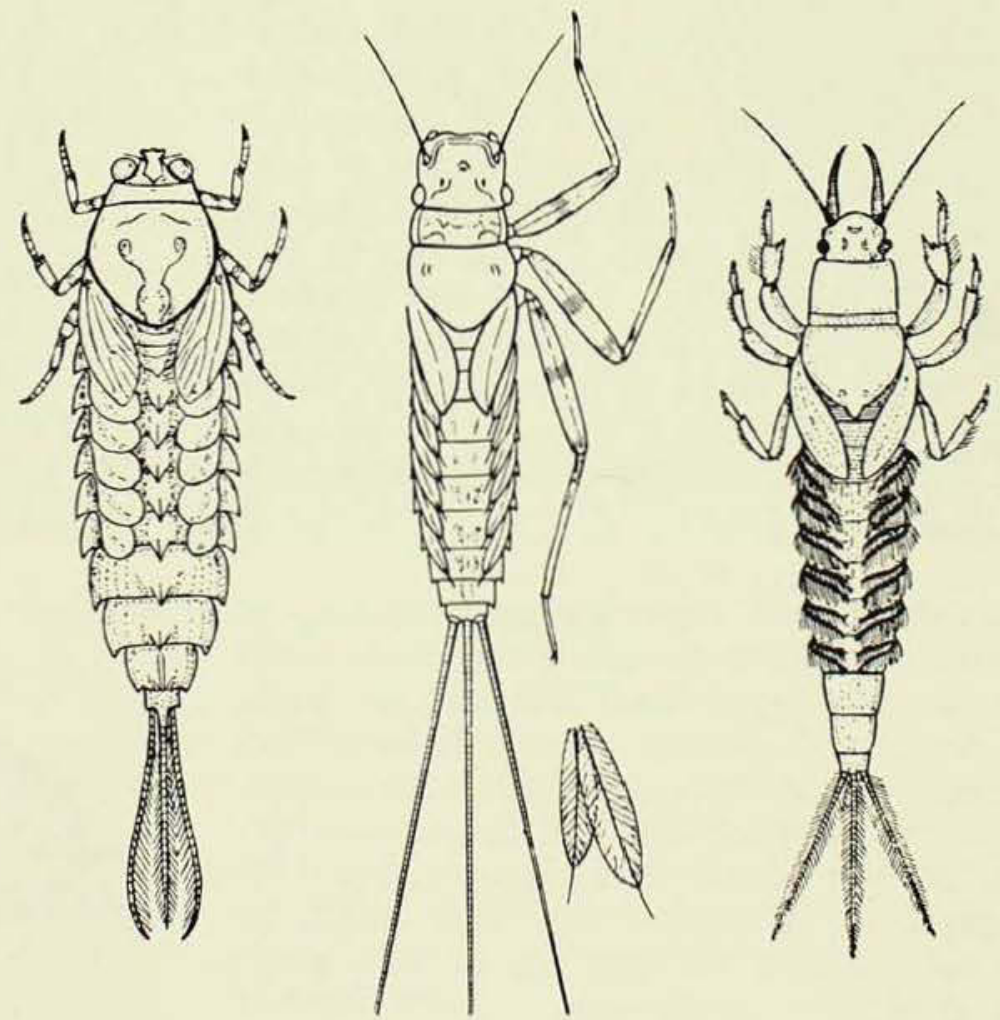
The only claim of mayflies to economic importance is the fact that both adults and larvae are eaten in large numbers by freshwater fishes, especially trout. Many of the "flies" used by fishermen are replicas of mayflies. Where rivers have been stocked with introduced trout many of the mayfly species seem doomed to extinction, for they cannot breed quickly enough to make up for the ravages of the fish. It is probable, therefore, that many species will be extinct before they are made known to science.

Because such a short time is passed as a winged insect it is much easier to find mayfly larvae than adults. The adults of a species may all emerge within a few days of each other at a certain time of the year, so that only by visiting the habitat on the right date will they be seen. Consequently, there are numerous kinds only known from the larvae.

Undoubtedly the most interesting mayflies of which the adult makes a very fleeting appearance are those of the genus Prosopistoma, which occurs in Europe, Africa, Madagascar and the East Indies. The larva is of very peculiar shape. The thorax is enlarged into a shield-like carapace which covers the whole of the insect, except the head and the tip of the abdomen, and encloses the gills in a branchial chamber. The appearance is, indeed, most unlike other mayfly larvae. It is not surprising, therefore, that its true nature was not at first realised, for when first discovered in France in 1762 it was thought to belong to the Crustacea, that large group of animals which includes the crabs, shrimps, crayfish and their allies. Even as late as 1833, when Latrielle bestowed on it the name Prosopistoma, it was still thought to be a branchiopod crustacean.

Though later in the nineteenth century it was rediscovered and recognized as a mayfly larva the winged form had still not been seen, and some thought that it reproduced and died in the aquatic phase. Vayssière, in 1881 , was able to discount this idea when he reared two female subimagos in captivity and expressed the opinion that this might be the final stage of the species, as the specimens died in a short time without further

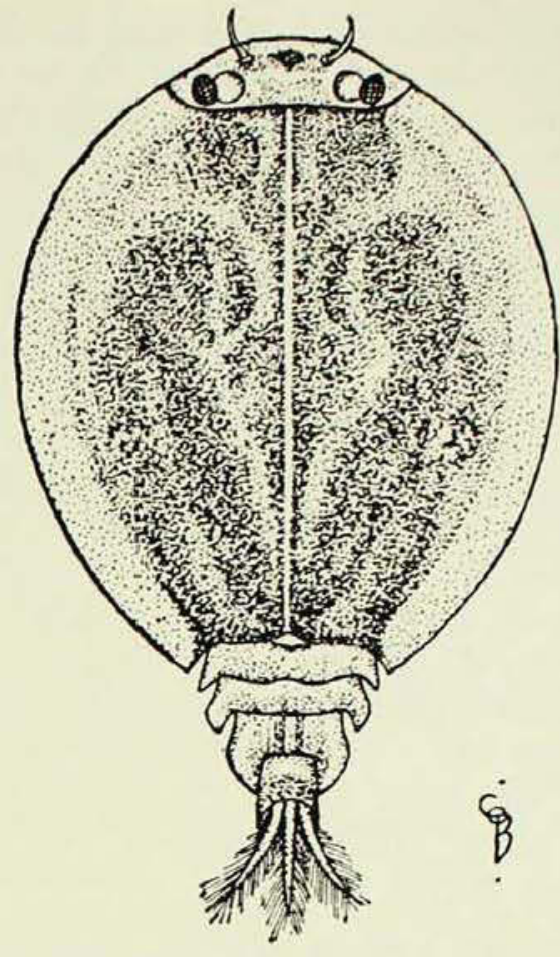

Larva (above) and female subimago (below) of an aberrant mayfly, Prosopistoma africanum (East Africa). Length of larva a quarter of an inch, of subimago a seventh of an inch.

After Gillies.

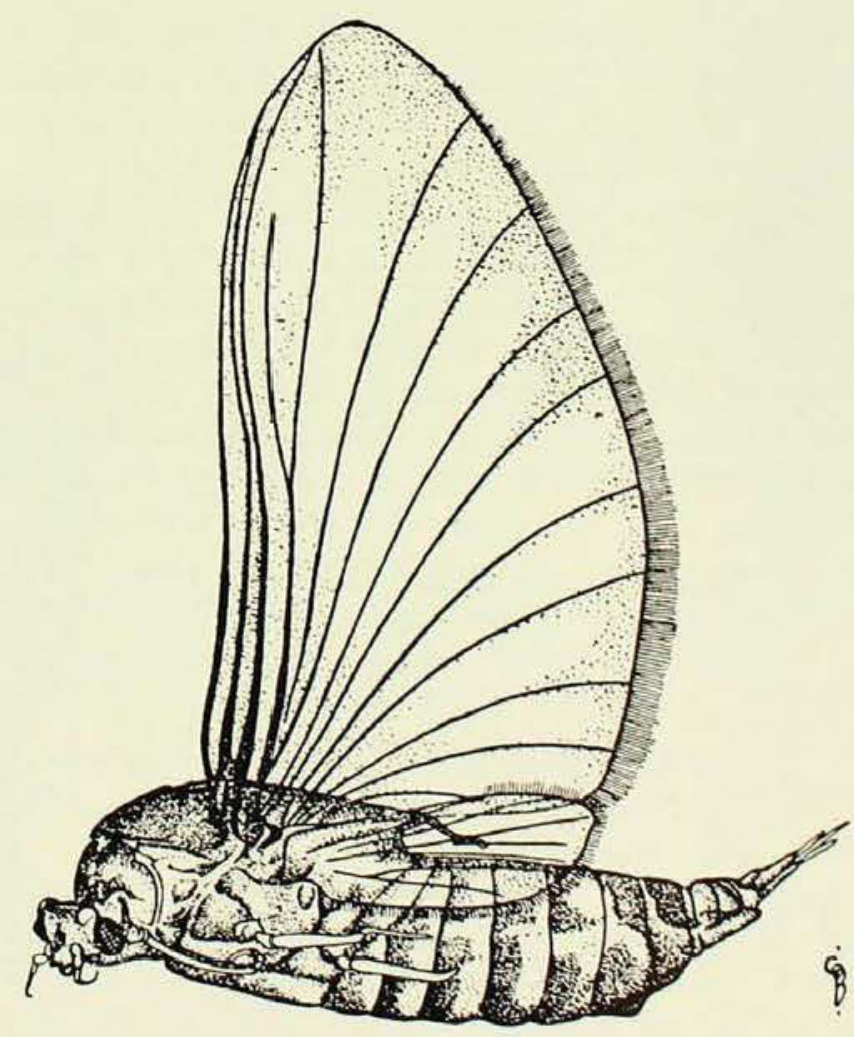

The Australian Museum Magazine 
change. Vayssière was criticized by some for his assumption, while others completely overlooked his work.

Quite recently M. T. Gillies, working with an African species, once again reared the winged forms, publishing his work in 1954. Gillies showed that the work of Vayssière was substantially accurate. The male reaches the imago stage while the female reproduces and dies as a subimago. Furthermore, the legs of the female subimago are so poorly developed as to be useless and to prevent it settling again after emergence. Adults were only seen in the 45 minutes immediately following dawn, and it is assumed that this is the full life-span of the post-larval stages. It is no wonder that they had not been encountered before by collectors.

\section{" THE VERTEBRATE TREE"}

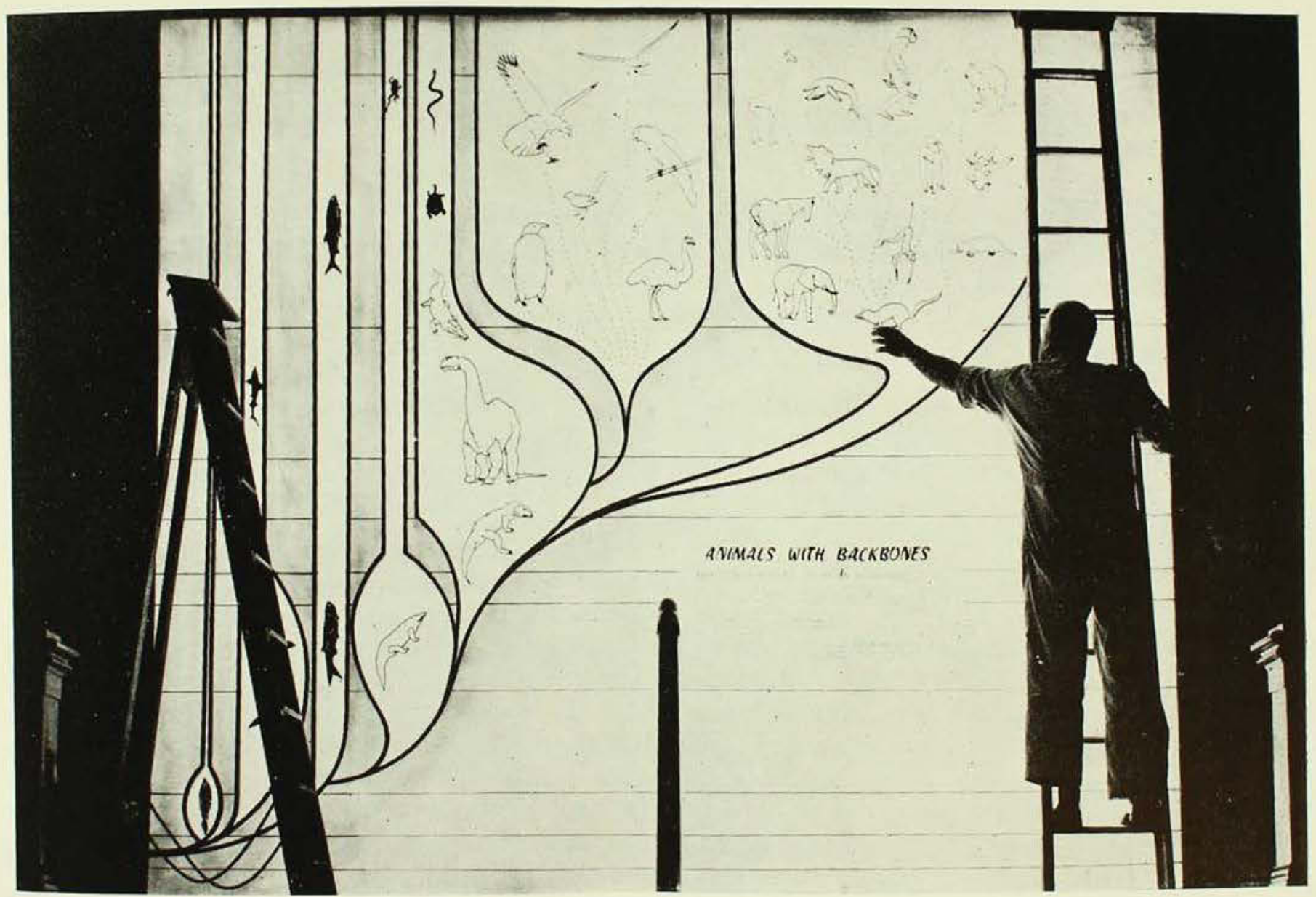

A unique new exhibit, "The Vertebrate Tree," has been installed at the head of the main stairway of the Australian Museum, facing the entrance. Constructed of welded steel, it shows the inter-relationships of the main groups of animals with backbones and the geological periods at which particular evolutionary developments took place. The figures of animals are silhouetted against a background of translucent fibreglass, behind which 60 fluorescent tubes provide the lighting. The exhibit is part of the Museum's commemoration of the centenary of the publication of Charles Darwin's book, "The Origin of Species," and is complementary to a previously completed exhibit, "These Are Invertebrates," which shows the inter-relationships of the main groups of animals without backbones. 


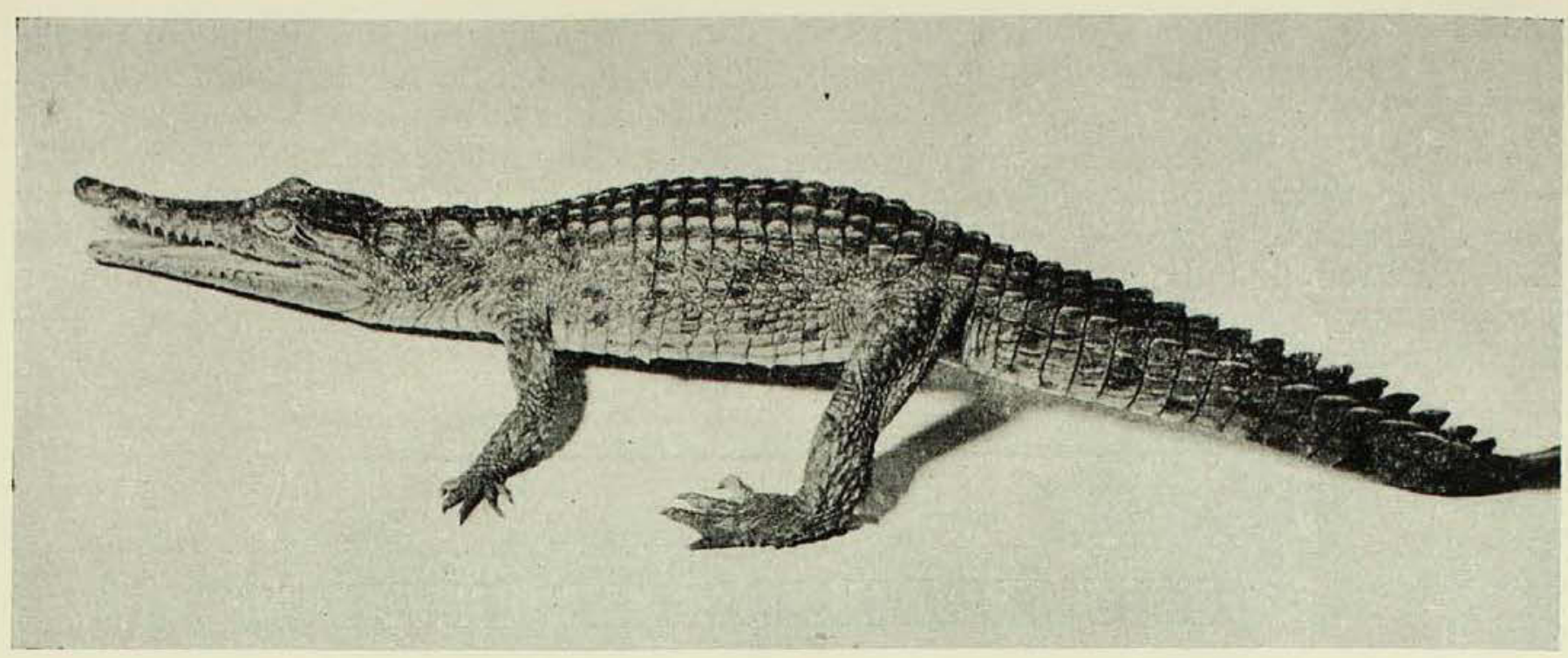

The Fresh-water Crocodile (Crocodylus johnstoni), a small species which inhabits the rivers and lagoons of northern Australia.

\section{Crocodiles And Their Kin}

By HAROLD G. COGGER

CROCODILES belong to an ancient reptilian order, the Crocodilia, the members of which first occurred in the Jurassic period, about $150,000,000$ years ago. Many of these early crocodilians were quite unlike modern forms, being enormous creatures which walked upright on their hind legs.

Modern members of the order, however, are generally divided into four groupscrocodiles, alligators, caimans and gavials.

Crocodiles may be distinguished by their moderately long, tapering, rather triangularshaped snouts. They occur in Africa and Madagascar and through India and Malaysia to northern Australia; there - are also several species in tropical South America, with only one species reaching the southern United States.

True alligators are blunt-nosed forms which occur only in the south-eastern corner of the United States and in China. Caimans, which are relatively blunt-nosed forms similar to alligators, are found only in South America. Gavials, on the other hand, have very long slender snouts, and occur only in India and Malaya.
One of the perennial questions asked of the Museum is "What is the difference between a crocodile and an alligator, and are there any alligators in Australia?"

The answer to the first part of this question is that there are a number of rather specialized structural differences between an alligator and a crocodile, one of the most obvious (but not the most important) being that in the latter the fourth tooth in the lower jaw fits into a notch in the upper jaw and is still visible when the mouth is closed. In alligators, however, the fourth tooth fits into a socket and is rarely visible when the mouth is closed.

\section{No Alligators In Australia}

The second part of the question is often confused by the fact that Australian crocodile hunters refer to the estuarine or seagoing crocodile (Crocodylus porosus) as a "'gator", to distinguish it from the smaller fresh-water crocodile (Crocodylus johnstoni). This is, of course, erroneous, for they are both true crocodiles and the only crocodilians found in Australia. 


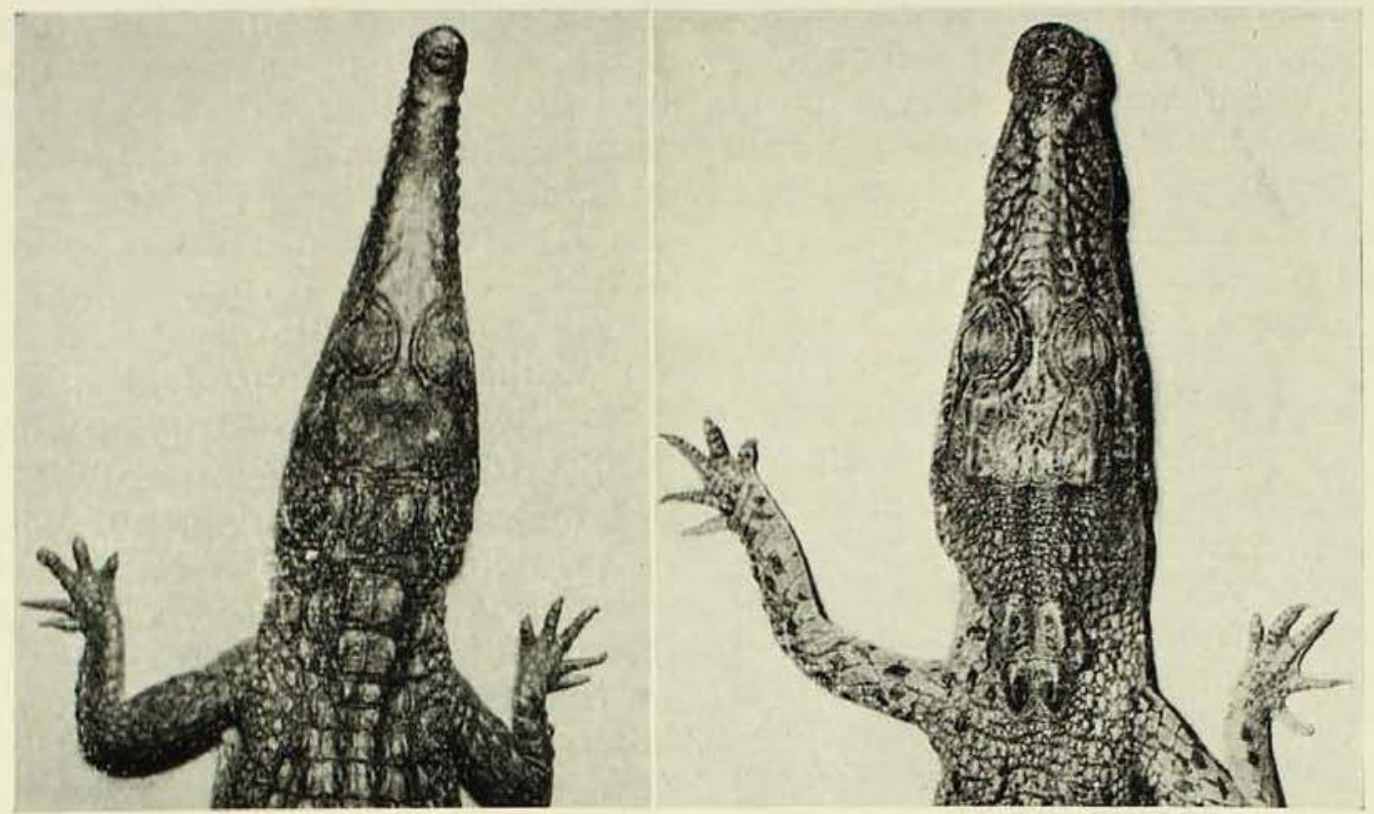

Heads of the two species of crocodiles found in Australia. Left: the Fresh-water Crocodile (Crocodylus johnstoni), which grows to about $8 \mathrm{ft}$. in lengih. Right: the Lstuarine Crocodile (C. porosus), believed to reach $30 \mathrm{ft}$.

C. porosus, as its common names would imply, is found largely in estuarine waters, and commonly takes to the open sea. It is widely distributed from India to Southern China, Malaysia, New Guinea and northern Australia. $C$. johnstoni is found only in the rivers of northern Australia.

Although there are some structural differences between the various kinds of crocodilians, they all possess a number of features in common. Their skin is very thick and leathery, and is strengthened on the back by a series of close-set bony plates termed "osteoderms". These bones are situated just below the surface of the skin, and are to a large extent responsible for the well-known ability of crocodilians to deflect a powerful blow or bullet. Similarly, the softer underside of a crocodilian is partly protected by a series of gastralia, or "abdominal ribs", which are not attached to the main skeleton.

As noted earlier, the form of the snout varies considerably. However, the jaws are invariably equipped with numerous strong, sharp teeth which are used only for grasping their prey, and not for chewing, as the food is swallowed whole. These teeth are constantly replaced.

The limbs, though relatively short, are thick-set, powerful and equipped with strong claws. Typically, the fore limb has five fingers which are webbed only at their base. The hind limb, however, has only four toes, usually with extensive webbing between them.

The amount of webbing is largely correlated with function. In swimming, the fore limbs are folded back along the body to provide minimum resistance to the body's motion through the water, and under such conditions webbing would be of little value. In rapid movement through the water the hind limbs are similarly placed, and the motive power is obtained from the swishing of the large, compressed, muscular tail. However, when a crocodilian is quietly floating the webbed, rather duck-like hind feet are moved slowly, and by "treading water" in this way the animal can remain in the same spot for a long time. From this it can be seen that the webbing on the hind feet is a distinct advantage. Another point is that in the breeding season the female uses her forefeet to excavate a nesting chamber, and it can be appreciated that delicate webbing would be quickly rendered useless in such a process if the feet were extensively webbed.

\section{Valves In Nostrils}

The nostrils are on the upper surface of a small mound on the tip of the snout. Small flaps of tissue in them act as valves to close 
off the respiratory passages when the crocodilian is submerged. So that the animal can open its jaws under water to feed without taking water into its throat, there is a fold of tissue on the upper surface of the base of the tongue which meets a similar fold on the palate and closes off the mouth from the respiratory passages. As a further adaptation to breathing with the mouth open, the bones on the roof of the mouth form a complete secondary palate, as in mammals, so that the passage from the nostrils enters the throat behind the level of the two folds of tissue. In this way a crocodilian is able to lie in the water with only the tip of its snout above the surface, at the same time leaving its jaws open in readiness to take its prey. Although the animals can catch their food under water, they almost invariably hold their heads above the surface when swallowing it.

When floating with only the tips of their snouts or the tops of their bodies above the surface they are often mistaken for floating $\operatorname{logs}$.

Another important feature of crocodilians is the presence of scent glands, which achieve their greatest development during the breeding season. They occur in both sexes. One pair is situated on the throat, one on the inner side of each of the lower jaws. Their secretions empty into a pocket or sac (for storage), which in turn reaches the exterior by a slit-like opening on the outside of the throat. Another pair of glands is situated inside the vent, and is not visible from the outside. The secretions from these glands are apparently important in sex recognition and location.

Internally there are a number of features of particular interest from the evolutionary point of view. These include the complete divison of the ventricle of the heart (with its resultant effects on the circulation of the blood), the high development of the lungs, and a non-muscular "diaphragm" which separates the thoracic from the abdominal cavity. This "diaphragm" is continuous with a diaphragmatic muscle, which apparently assists in respiration.

\section{Female Lays 70 Eggs}

In Australia the breeding season extends from October to December, the females coming ashore at this time to lay their eggs

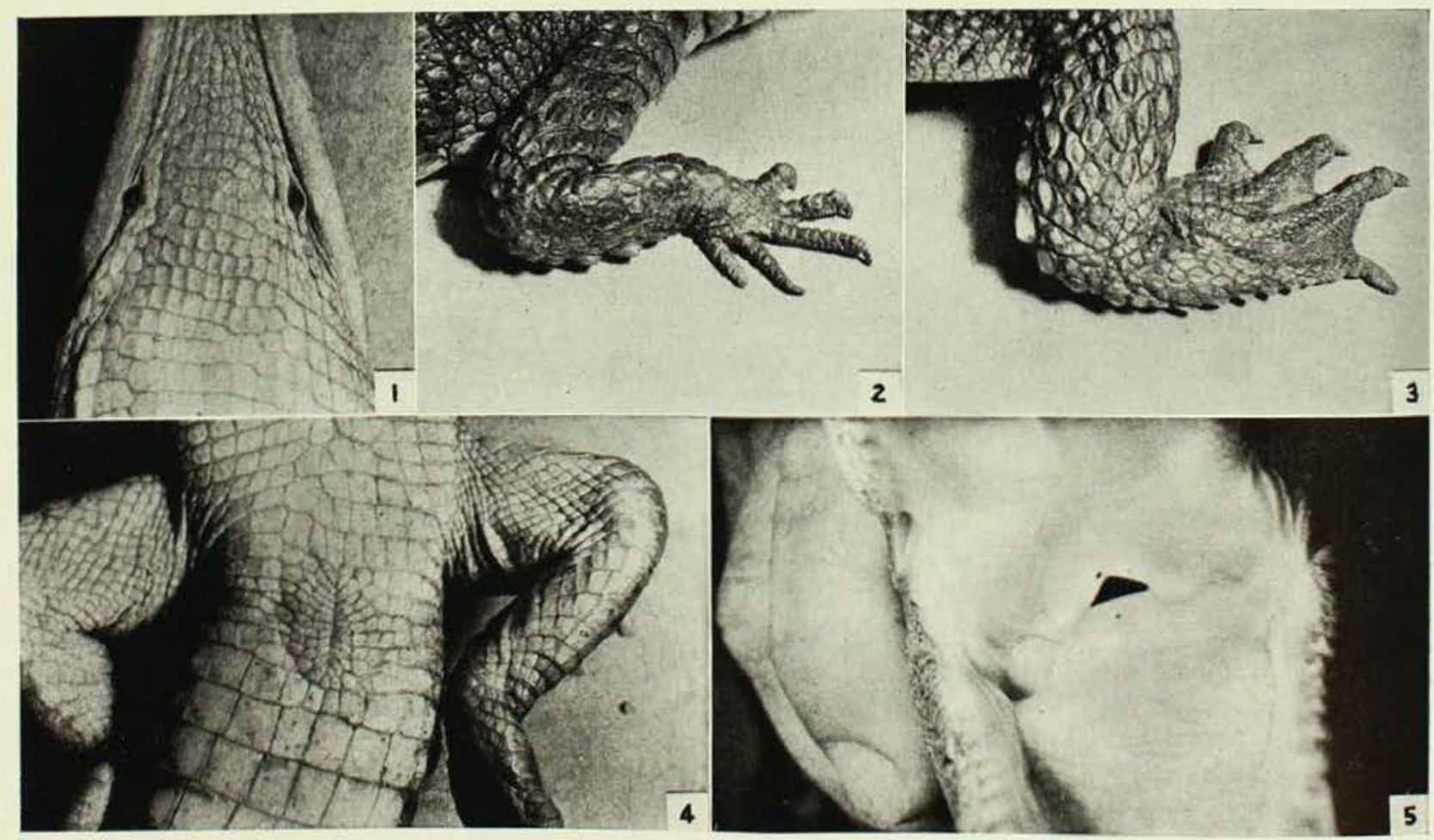

Some characteristics of crocodiles: 1. Scent glands on the throat. 2. The forefoot, showing the five toes without webbing. 3. The hind foot, with the four toes extensively webbed. 4. The longitudinal vent, unique among present-day reptiles. 5. The folds of tissue which seal off the respiratory passages from the mouth when the crocodile is submerged. 
in a shallow hole scraped out by their forefeet in the soft earth of a river bank. Here the female lays 70 or more eggs (in the case of the estuarine crocodile), each about 3ins. long, and then covers them with soil and leaves. It has been reported that in certain foreign species the female remains in the vicinity of the nest, guarding the eggs until they hatch. This is not known to occur in either of the Australian species, however, the females taking no further interest in the eggs once they are laid. The eggs are incubated by the warmth of the tropical sun, together with that produced by the decaying vegetable matter scraped back into the nest by the female.

The eggs usually take between five and eight weeks to hatch, the young cutting their way out of the leathery, parchmentlike shell with a special "egg-tooth" on the tip of the snout. This tooth is lost soon after birth. The young burrow through the nest to the surface, and immediately make for the water. The newly-hatched young of $C$. porosus are about 11 ins. in length.

Most of the young crocodiles fall prey to a variety of animals, such as the larger fish, lizards, birds and mammals. They are often eaten by larger specimens of their own kind. Adult crocodiles, however, have few enemies other than man, who hunts them for their skin, which makes a tough and decorative leather. In many countries both crocodiles and their eggs are prized as food by the natives.

Although crocodiles spend most of their time in the water, they often emerge on to the banks of streams and inlets and on to sandbars, to bask in the sun. If disturbed, they quickly make for the water again, and, despite their massiveness, can lift their bodies well off the ground and move away rapidly.

Most species feed largely on fish, but also eat a wide variety of other animals, including frogs, tortoises, lizards, snakes, birds and mammals.

Crocodiles usually catch such prey as water birds by remaining submerged and moving stealthily to a point below the bird, which, unaware of the crocodile's presence, is quickly seized in the powerful jaws. Similarly, by lying submerged the crocodile is able to grasp any animal (including man) which comes to the water's edge to drink or bathe. Once caught, an animal is dragged into the water and held beneath the surface until it drowns, when it can be eaten at leisure.

\section{Man-Killers}

Although few crocodiles are considered a menace to man, there are two species which merit attention in this regard. Perhaps the most notorious is the Estuarine Crocodile, large specimens of which have been known to kill and eat both adults and children. The African Crocodile (Crocodylus niloticus) is also a species which has a nasty man-eating record. Some writers have suggested that individual crocodiles, once they have learned that humans are relatively defenceless prey, become inveterate man-eaters. Certainly, there are enough authentic records of both successful and unsuccessful man-eating attempts by Australia's $C$. porosus to cause it to be treated with the greatest caution.

Despite many reports to the contrary, the alligator is a relatively docile and sluggish creature, although, like the crocodiles, it can show an amazing turn of speed either when threatened or pursuing its prey. It becomes very tame in captivity, and even in its native haunts is not generally considered a menace, for it has rarely been known to attack a man.

Crocodiles, however, are the very essence of savagery and viciousness, this temperament being usually exhibited by young and adult alike, and even in specimens which have been long in captivity.

\section{Crocodiles' Size}

The size of crocodilians varies considerably. Most crocodiles and the American alligator seldom reach a length of more than $15 \mathrm{ft}$. The Indian Gavial (Gavialis gangeticus) is believed to attain a length of nearly $30 \mathrm{ft}$; fortunately this species is rather timid and feeds almost entirely on fish. The African Crocodile and the Madagascar Crocodile (C. robustus) are both believed to grow to about $25 \mathrm{ft}$. in length, while the Estuarine Crocodile has been recorded as reaching more than $30 \mathrm{ft}$.

In the Americas, the largest crocodilian is the Black Caiman (Caiman niger) of 
tropical South America; this species probably grows to nearly $20 \mathrm{ft}$. in length. The Fresh-water Crocodile of northern Australia has a maximum size of about 8 ft.

It should be mentioned, however, that the sizes recorded in this article are generally based on records made during the last century; because of activities of skin-hunters and others, it is most unlikely that such enormous specimens could survive and be found today.

The age to which crocodiles live has been a subject of some contention. Some earlier writers have blandly stated that crocodiles commonly live to a ripe old age of more than 1,000 years. Others, more conservative, say
500 years. Unfortunately, it is difficult to obtain an authentic figure, for little is known concerning either absolute age or growth rates. However, in captivity it has been found that newly-born alligators ( 7 ins. in length) reach sexual maturity and a length of more than five feet within five years, so it appears that growth (at least in the early years) may be more rapid than was previously believed. Nevertheless, once a size of about $10 \mathrm{ft}$. is attained annual growth is usually very small. For this reason, most writers consider that crocodiles probably achieve an age of $50-100$ years, but perhaps one should not rule out the possibility that very large specimens may be close to 200 years of age.

\section{[Photos by the author]}

\section{Origin of Museum's Whale Skeleton}

The skeleton of a whale which has been seen by so many visitors to the Australian Museum over the years has an interesting history. The whale, $35 \mathrm{ft}$. long and weighing more than four tons, was found stranded in shallow water off Foulness, Essex, England, on November 2, 1883, by two brothers, Harry and Walter Page, who were fishing for sprat. It took the brothers and many helpers two days to haul it ashore at Southend-on-Sea with harpoons and ropes. The brothers exhibited the whale to the public in a field at the back of a hotel, and were doing very wall financially when the lord of the manor, Sir Henry Mildmay, heard about it. He promptly claimed the mammal as "fish royal," and won the resultant chancery suit after citing a similar case in 1677 , in which the then lord of the manor had been awarded the prize. The Curator of the Australian Museum, Dr. E. P. Ramsay, who was in England at the time, bought the whale from Sir Henry. Reporting on it to the Trustees of the Museum, he wrote: ". . . . one from the coast of England, belonging to the extremely rare species known as Rudolphi's Whale (Balaenoptera corealis), of which I had the good fortune to secure a specimen in the flesh before leaving London . . . ."

\section{Japanese Visit Museum}

When the M.V. Koyo Maru, a training and research ship of the Shimonoseki College of Fisheries, Japan, was in Sydney last December, Captain Minami, Professor Isao Matsui, interpreters and 72 cadets visited the Australian Museum and were shown the collections.

\section{Check-list of Fishes}

Mr. Richard Slack-Smith, of the Fisheries and Game Department, Melbourne, visited the Australian Museum in January to inspect specimens of freshwater fishes. $\mathrm{He}$ is also preparing a check-list of the coral fishes of Heron Island, Queensland. 